Fall 2011

\title{
A Clash of Paradigms in the Water Sector - Tensions and Synergies between Integrated Water Resources Management and the Human Rights-Based Approach to Development
}

Hugo Tremblay

\section{Recommended Citation}

Hugo Tremblay, A Clash of Paradigms in the Water Sector - Tensions and Synergies between Integrated Water Resources Management and the Human Rights-Based Approach to Development, 51 Nat.

Resources J. 307 (2011).

Available at: https://digitalrepository.unm.edu/nrj/vol51/iss2/7

This Article is brought to you for free and open access by the Law Journals at UNM Digital Repository. It has been accepted for inclusion in Natural Resources Journal by an authorized editor of UNM Digital Repository. For more information, please contact amywinter@unm.edu, Isloane@salud.unm.edu, sarahrk@unm.edu. 


\title{
A Clash of Paradigms in the Water Sector? Tensions and Synergies Between Integrated Water Resources Management and the Human Rights- Based Approach to Development**
}

\begin{abstract}
A variety of paradigms shape water resources management, reflecting the evolution of government policies and transient societal values. Integrated Water Resources Management (IWRM) became a predominant management framework in the 1990s whereas the Human Rights-Based Approach (HRBA) to development emerged recently as an influential approach in the water sector. While IWRM and the HRBA overlap significantly, the interactions between these two remain largely unexplored, and their repercussions may be significant. Because IWRM and the HRBA do not share identical premises and objectives, concurrent implementation of the two might also lead to tensions detrimental to water resources management. The purpose of this article is to explore the interactions between IWRM and the HRBA to development in the water sector. Questions raised by perceived conflicts are identified to help address potential tensions when the two approaches coexist. Synergies between IWRM and the $H R B A$ are also detailed to establish how the two approaches are aligned.
\end{abstract}

"Most Covenant rights are, at base, claims to scarce resources, and decisions regarding their recognition and enforcement will necessarily involve questions of resource allocation."1

* Ph.D. student, United Nations Educational, Scientific, and Cultural Organization (UNESCO) Centre for Water Law, Policy and Science, University of Dundee, Scotland; Member of the Québec bar.

** Research for this article was realized in the context of the January 22-23, 2009, Workshop for the IWRM and HRBA Initiative at the UNESCO Centre for Water Law, Policy, and Science, University of Dundee. I wish to thank the participants to the workshop whose reflections provided invaluable material for this article. I am especially grateful to my supervisor Professor Patricia Wouters, Professor Dan Tarlock, and colleagues Mohamad Mova Al'Afghani and Dinara Ziganshina, as well as to various anonymous peer reviewers for their insightful comments and guidance. The opinions expressed herein are strictly personal. Any error or omission is mine.

1. Michael Dennis \& David Stewart, Justiciability of Economic, Social, and Cultural Rights: Should There Be an International Complaints Mechanism to Adjudicate the Rights to Food, Water, Housing and Health?, 98 Am. J. INT'L L. 462, 512 (2004). 


\section{INTRODUCTION: CONTEXT AND SCOPE}

As a discipline, water resources management has been shaped by a variety of paradigms reflecting the evolution of prevailing government policies and transient societal values. ${ }^{2}$ Since the 1930 s, water resources management has undergone a series of rapid shifts from the ethics of resource exploitation to resource conservation and sustainable resource management. ${ }^{3}$

Through this process, Integrated Water Resources Management (IWRM) became the predominant water management paradigm in the 1990s. However, the Human Rights-Based Approach (HRBA) to development has recently emerged as an influential approach in the water sector following the United Nations (U.N.) Millennium Declaration ${ }^{4}$ and the progressive emergence of a human right to water at the international level. Recently, additional momentum has been imparted to the HRBA by the U.N. General Assembly recognition of the human right to water and sanitation.

IWRM and the HRBA to development propose broad management frameworks that significantly overlap in the water sector. The interactions between the two remain largely unexplored, although their repercussions are significant. Because IWRM and the HRBA do not share identical premises and objectives, the concurrent implementation of the two might lead to tensions detrimental to water resources management. ${ }^{5}$

2. Bruce Hooper, Integrated River Basin Governance: Learning from InternaTIONAL EXPERIENCES 2-3 (2005).

3. Id. at 2. This has not solved the problems in water management. Barely a day passes without news confirming the gravity of the impending world water crisis, which has even been acknowledged at the January 2009 World Economic Forum in Davos. See World Economic Forum Water Initiative, The Bubble Is Close to Bursting: A Forecast of the Main Economic and Geopolitical Water Issues Likely to Arise in the World During the Next Two Decades, Draft for Discussion at the 2009 Annual Meeting (2009), http://www.weforum.org/pdf/water/WaterInitiativeFutureWaterNeeds.pdf. The crisis has been long in the making, and protracted efforts directed at solving it have so far been globally unsuccessful. See also Malin Falkenmark, Water Scarcity-Challenges for the Future, in The Scarcity of Water. Emerging Legal and Policy Responses 136 (Edward H.P. Brans et al. eds., 1997) (aptly summarizing the fundamental drivers underlying the impending crisis).

4. United Nations Millennium Declaration, G.A. Res. 55/2, U.N. GAOR, 55th Sess., 8th Plen. Mtg., Agenda Item 60(b), U.N. Doc. A/RES/55/2 (Sept. 18, 2000). Resolution on the Human Right to Water and Sanitation, G.A. Res. 64/292, U.N. GAOR, 108th Plen. Mtg., Agenda Item 48, U.N. Doc. A/64/L.63/Rev.1 at 3 (July 28, 2010) declares "the right to safe and clean drinking water and sanitation as a human right that is essential for the full enjoyment of life and all human rights."

5. A summary description of the interface between IWRM and the HRBA mentions that: "[L]inking and gaining synergies between the two approaches poses some challenges of clarifying perceived conflicts between the approaches and identifying ways to align 
The purpose of this article is to explore the interactions between IWRM and the HRBA to development in the water sector. ${ }^{6}$ Questions raised by perceived conflicts are identified to help address possible tensions when the two approaches coexist. Synergies between IWRM and the HRBA are also detailed to establish how the two approaches are aligned. Issues related to drinking water and sanitation services and the human right to water are addressed. However, the scope of this study is broader, examining all aspects of water resources management potentially affected by the interactions between the two approaches, including their effects on domestic, agricultural, industrial, and environmental water uses.

This article is an opinion paper. It adopts a synthetic perspective and does not offer an exhaustive review of the issues related to IWRM and the HRBA. The overarching argument contends that imperfections within each approach can be remedied by conjoining the two, despite some tensions that must be addressed and solved by water managers at the local or national level on a case-by-case basis. On one hand, the integrative function of IWRM anchors the HRBA in the physical context of water resources management and helps clear up apparent ambiguities in the latter. On the other hand, the HRBA provides substantive direction to increase equity in water management reform processes and offers essential discursive recourses against structural imbalances within integrated management frameworks. ${ }^{7}$ Intertwining IWRM and the HRBA is beneficial to both. However, this article does not claim that such conjoining would solve all challenges related to water management or that all other water management paradigms are inferior or useless. ${ }^{8}$ Rather, lessons can be learned from both.

them in practice." See WATERWiKI, Human Rights-Based Approach, http:/ /www.waterwiki. net/index.php/Human_Rights-Based_Approach (last updated Dec. 15, 2010).

6. This article does not aim to further detail the respective definitions of IWRM and HRBA. The already abundant and still expanding literature on these subjects is only summarized and referenced as a basis for a discussion on the interactions between the two approaches, which is the essential purpose of the article.

7. The term "discursive" is employed throughout the article in its usual, rather than philosophical sense, to mean without predefined structure or quality. It refers to a nonsystematized logic that evolves contextually.

8. While other water management approaches, such as soft paths or adaptive management, can offer various benefits, this article does not consider them. It could be argued that IWRM and the HRBA are singled out amongst a plethora of approaches for the purpose of this article because they currently enjoy apparent prominence in the water management discourse. But, at bottom line, the most robust justification for this article is that the interface between IWRM and the HRBA remains inadequately researched despite initial forays. See Susanne Schmidt, Water Governance Specialist, United Nations Bureau for Development Policy, Presentation at the World Water Week: A Human Rights Based Ap- 
The article is divided as follows: First, short, contextual definitions are provided for both IWRM and the HRBA to development in the water sector (Part II). Second, five areas of tension between the two are identified, and questions resulting from their coexistence are raised to indicate issues that should be addressed by water management frameworks (Part III). Finally, several synergies between IWRM and the HRBA are explored in order to determine how combining the two approaches can improve equitable development and the sustainable management of water resources (Part IV).

\section{IWRM AND THE HRBA: DEFINITIONS}

This Part briefly defines IWRM (Part II.A) and the HRBA to development in the water sector (Part II.B) to provide a basis for the discussion that follows.

\section{A. Defining IWRM: Aiming at a Moving Target?}

IWRM emerged as a dominant paradigm for water resources management in the early 1990s. Although this approach existed under various guises for decades prior to that time, the materialization of IWRM is often linked to the Dublin Principles and Agenda 21. ${ }^{9}$ Since

proach to IWRM: Exploring Synergies (Sept. 5-11, 2010), http://www.worldwaterweek. org/documents/WWW_PDF/2010/thursday/T3/IWRM-HRBA_WWW_2010_PRES.pdf. This is a typical stance in some fields of research, among them legal studies, where accumulation of knowledge is a valid end in itself without further need for justification. In this context, the article belongs to an emerging research domain that explores the interactions between various management paradigms in the water sector. Bilateral interactions between other management frameworks have been explored, as is the case for the interface between IWRM and adaptive management. See Wietske Medema, Brian S. McIntosh \& Paul J. Jeffrey, From Premise to Practice: A Critical Assessment of Integrated Water Resources Management and Adaptive Management Approaches in the Water Sector, 16 Ecology \& Soc'Y, no. 2, art. 27 (2008), available at http:/ / www.ecologyandsociety.org; see also WiETSKe MEDEMA \& PAUL Jeffrey, IWRM and Adaptive Management: Synergy or Conflict?, NeWater Report SeRIES No. 7, 18 (2005), http://www.usf.uni-osnabrueck.de/projects/newater/downloads/ newater_rs07.pdf (noting that it is crucial to explain the reasons for combining two management approaches in the water sector). Hence, this article attempts to detail some of the interactions between IWRM and the HRBA to fill a gap in the literature, but also to stimulate the drive toward holistic, inclusive, systemic, comprehensive, or integrated resources management that presumably requires that coexisting management approaches take each other in to account.

9. See Dublin Statement on Water and Sustainable Development, Dublin, Ireland (Jan. 31, 1992), available at http://www.wmo.int/pages/prog/hwrp/documents/english/icwedec e.html [hereinafter Dublin Principles]; United Nations Conference on Environment and Development, Rio de Janeiro, Braz., June 3-14, 1992, Agenda 21: A Programme for Action for Sustainable Development, U.N. Doc. A/CONF.151/26 (Vol. II), Annex II (Jun. 13, 1992) [hereinafter Agenda 21]. For a synthetic review of the development of IWRM, see Muhammad 
then, global commitment to IWRM has been reaffirmed in numerous international fora such as the Johannesburg World Summit on Sustainable Development, in 2002, and has been developed into a detailed conceptual framework for water resources management. ${ }^{10}$

IWRM is perceived as the conceptual vehicle that promotes sustainable development in the management of freshwater resources. ${ }^{11}$ IWRM is a holistic approach applicable to all water resources and water uses as a response to the failures of fragmented water management regimes. ${ }^{12}$ Although various definitions exist, the authoritative IWRM statement is provided by the Global Water Partnership: "IWRM is a process that promotes the co-coordinated development and management of water, land and related resources, in order to maximize the resultant economic and social welfare in an equitable manner without compromising the sustainability of vital ecosystems."13

IWRM identifies various elements for good water governance that span the areas of policy, legislation, institutional capacity and frameworks, financial instruments, social development, and scientific research. ${ }^{14}$ IWRM's overriding principles are economic efficiency in water

Mizanur Rahaman \& Olli Varis, Integrated Water Resources Management: Evolution, Prospects and Future Challenges 1 Sustainability: SCI., Practice, \& Pol'y 15 (2005).

10. See U.N. World Summit on Sustainable Development, Johannesburg, S. Africa, Aug. 26-Sept. 4, 2002, Declaration on Sustainable Development, Report of World Summit on Sustainable Development, U.N. Doc. A/Conf.199/20 (2002). For a recent international recognition of IWRM, see United Nations, Econ. \& Soc. Council, Comm. on Sustainable Development, Report on the Sixteenth Session $51 \S 213$ (May 11, 2007, and May 5-16, 2008), U.N. Doc. E/CN.17/2008/17 (Supp. No. 9).

11. Antoinette Hildering, International Law, Sustainable Development and Water Management 32 (2004). See also Agenda 21, supra note 9, at Chapter 18.

12. See, e.g., U.N. Water, Status Report on Integrated Water Resources ManageMENT AND WATER EFFiciency Plans, PREPAREd FOR THE 16TH SESSION OF THE COMMISSION ON Sustainable Development 4-5 (May 2008), available at http://www.unwater.org/down loads/UNW_Status_Report_IWRM.pdf.

13. Global Water Partnership Technical Advisory Committee, Integrated Water Resources Management 22 (Global Water Partnership Tech. Advisory Committee Background Paper No. 4, 2000). Since the 2009 World Water Forum and World Water Week, many publications further detailing the definition and content of IWRM have been released. See, e.g., Integrated Water Management in Practice: Better Water ManageMENT for DeVelopment (Roberto Lenton \& Mike Muller eds., 2009).

14. On the issue of good water governance in the context of IWRM, see Håkan Tropp, Water Governance: Trends and Needs for New Capacity Development, 9 WATER POL'Y, Supp. 2, 19 (2007); Andrew Allan \& Alistair Rieu-Clarke, Good Governance and IWRM-A Legal Perspective, 24 Irrigation \& Drainage SYs. 239, 240-44 (2010); Anthony R. Turton et al., Towards a Model for Ecosystem Governance: An Integrated Water Resource Management Example, in Governance as a Trialogue: Government-Society-Science in Transition 1 (Anthony Turton et al. eds., 2007). 
use, social equity, and environmental and ecological sustainability. ${ }^{15}$ The concepts guiding the implementation of IWRM's principles are subsidiarity and inclusive participation, costs internalization and the userpays principle, precaution and prevention, transparency and accountability, river-basin management, and sound scientific assessments of physical constraints in natural resources management. ${ }^{16}$ In particular, IWRM recognizes the need for environmental water allocations in a context of finite water resources and competition among uses. ${ }^{17}$

In recent years, IWRM has been criticized as normatively empty or, alternatively, as a vehicle for a globalized neo-liberal agenda, as well as too vague, too broad in scope, and too difficult to implement. ${ }^{18}$ For example, one assessment states that IWRM:

is a sound philosophy which is hard to disagree with. However, in developing countries, what usually gets passed-off in the name of IWRM at the operational level takes a rather narrow view of the philosophy and has largely tended to include a blue-print package including: [1] A national water policy; [2] A water law and regulatory framework; [3] Recognition of River Basin as the appropriate unit of water and land resources planning and management; [4] Treating water as an economic good; and [5] Participatory water resource management. Several of these mark a significant shift from current paradigms and making this transition is proving to be difficult. Drafting new water laws is easy; enforcing them is not. Renaming regional water departments as basin organizations is easy; but managing water resources at basin level is not. Declaring water an economic good is simple; but using price mechanisms to direct water to high-value uses is proving com-

15. Global Water Partnership Technical Advisory Committee, supra note 13, at 30. Many authors provide similar enumerations with varying degrees of details that essentially cover the same values. See, e.g., A. Dan Tarlock, Integrated Water Resources Management: Theory and Practice, in Implementing Integrated Water Resources Management in CenTRAL AsIA 4 (Patricia Wouters, Victor Dukhovny \& Andrew Allan, eds., 2007); Peter Gleick, The Changing Water Paradigm: A Look at Twenty-First Century Water Resources Development, 25 WATER INT'L 127, at 131 (2000).

16. For an overview of principles guiding the operationalization of IWRM at the social level, see Frank G.W. Jaspers, Institutional Arrangements for Integrated River Basin Management, 5 Water Pol'y 77, 77-90 (2003).

17. See Kees Leendertse, Steve Mitchell \& Joakim Harlin, IWRM and the Environment: A View on Their Interaction and Examples Where IWRM Led to Better Environmental Management in Developing Countries, 34 WATER S.A. 691, 691-98 (2008).

18. See, e.g., Asit K. Biswas, Integrated Water Resources Management: Is It Working? 24 Int'L J. Water Resources Dev. 5, 13, 19 (2008); Mike Muller, Fit for Purpose: Taking Integrated Water Resource Management Back to Basics, 24 Irrigation \& Drainage SYs. 161, 164-65 (2010). 
plex. As a consequence, the so-called IWRM initiatives in developing country contexts have proved to be ineffective at best and counterproductive at worst. ${ }^{19}$

A study by François Molle, a senior researcher in international water issues, encompasses IWRM's critiques and helps pinpoint the approach's substantive core. ${ }^{20}$ That core, according to Molle, consists of a nirvana concept, a narrative, and a model. In this context, "nirvana concept" refers to an unattainable water management ideal that emphasizes process and can perpetuate the status quo because it might be hijacked for legitimization purposes. ${ }^{21}$ "Narrative" refers to a simplified and rationalized interpretation of reality, obscuring complex situations in which casual relationships are inherently blurred, and prescribing clearly defined and logically articulated goals that might be sound in particular contexts but constitute flawed generalizations. ${ }^{22}$ For example, economic efficiency through water markets is identified as a typical narrative that survives although the asserted inherent superiority of pure market allocation was debunked a long time ago. ${ }^{23}$ And lastly, "model" refers to a specific instance of reform or development intervention presented as a success story and transplanted through a reductionist process anchored in the technocratic expert planning that is justified by a belief in the replicability of solutions. ${ }^{24}$ For example, Chilean water markets are identified as a typical model of dubious value. ${ }^{25}$ Ultimately, it can be inferred from

19. International Water Management Institute, IWRM Challenges in Developing Countries: Lessons from India and Elsewhere 2 (IWMI, Water Policy Briefing 24, 2007), which is based on Tushaar Shah, Issues in Reforming Informal Water Economies of LowIncome Countries: Examples from India and Elsewhere, in COMMUNITY-BASED WATER LAW AND Water Resource Management Reform in Developing Countries 65 (Barbara van Koppen, Mark Giordano \& John Butterworth, eds., 2007).

20. François Molle, Nirvana Concepts, Narratives and Policy Models: Insights from the Water Sector, 1 WAter Alternatives 131, 132-36 (2008).

21. See id. at 132.

22. See id. at 136.

23. See Ronald H. Coase, The Problem of Social Cost, 3 J.L. \& Econ. 1 (1960). Some myths are resilient. See Michael R. Butler \& Robert F. Garnett, Teaching the Coase Theorem: Are We Getting It Right?, 31 AtLANTIC ECON. J. 133, 133-45 (2003). For an interesting study of transaction costs under prior appropriation doctrine that is based on a dubious interpretation of Coase's arguments, see C. Carter Ruml, The Coase Theorem and Western U.S. Appropriative Water Rights, 45 Nat. Resources J. 169 (2005).

24. See Molle, supra note 20 , at 138 .

25. At best, the value of this model is uncertain. See Carl Bauer, Bringing Water Markets Down to Earth: The Political Economy of Water Rights in Chile, 1976-95, 25 World Dev. 639 (1997). At worst, it can be claimed that true water markets have never existed, for raw water at least. See Joseph W. Dellapenna, The Market Alternative, in The Evolution of THE Law and Politics of Water 373 (Joseph W. Dellapenna \& Joyeeta Gupta, eds., 2009). 
Molle's critique that all of IWRM's principles could be construed as narratives and/or models.

Although Molle's conceptual depictions are appropriate, his critique does not affect the validity of IWRM as a normative paradigm for improved water resources management. First, conceptualizations of IWRM as a set of narratives and prescriptive models rest on the same foundations. Both narratives and models rely on identical mechanisms of simplification, rationalization, and generalization, which make these two concepts qualitatively indistinguishable. These mechanisms are common to most sectors of knowledge and activity, and, more specifically, are inherent to scientific reasoning and processes. ${ }^{26}$ Should some aspects of IWRM indeed function as models and narratives, such a characterization should not provide in itself a basis to disqualify the paradigm.

Second, Molle's efforts to demonstrate particular operational difficulties do not invalidate IWRM as a normative paradigm but rather identify specific instances of imperfect implementation that must be resolved through further improvement of the narratives and models used to guide the implementation of management frameworks. This implies that narratives and models are not inherently self-validating in the context of IWRM. It also intimates that such models and narratives must be transient expressions of IWRM that may be altered or shed if it is established that they do not fulfill their instrumental purpose.

Third, as these considerations emphasize a procedural dimension and allude to the existence of a core normative value, the characterization of IWRM as a nirvana concept must then be examined. This leads to the conclusion that IWRM is not normatively empty, but rather provides substantive guidance in water management reforms even if it is reduced to a nirvana concept. Molle presents IWRM as a "boundary object," i.e., a collective construct that serves as a common ground and ultimate objective for all stakeholders concerned with water management in order to develop a dialogue and a unified framework for action. ${ }^{27}$ From this perspective, the overarching normative concept that binds the discourse and improves water management is the integrative dimension of IWRM. As such, IWRM's primary function is to increase the coherence and cohesiveness of disparate activities, knowledge, and principles related to water resources. This function must be distinguished from coordination

26. See Carl G. Hempel \& Paul Oppenheim, Studies in the Logic of Explanation, 15 PHIL. OF SCI. 135, 138 (1948).

27. See Molle, supra note 20, at 132, 136. See also Mike Bonell, How Do We Move from Ideas to Actions? The Role of the HELP Programme, 20 InT'L J. WAter Resources Dev. 283, 285 (2004) (expressing the view that "[a] key element of IWRM is the gathering and sharing of data and information related to the hydrological, environmental, economic and social sciences.") 
because the latter does not necessarily imply balanced viewpoints, tradeoffs, and sectoral constraints. ${ }^{28}$ Dimensions of narratives and models inconsistent with further integration of the management framework must be discarded or streamlined. However, perfect integration is ultimately unattainable. ${ }^{29}$

Thus, IWRM's normative core can be reduced to a principle of integration. This minimalist perspective is in line with some definitions of IWRM and corresponds to IWRM's function in the legal domain, where it acts as a federating principle that requires sectoral elements of the legal framework-such as legislation regulating agricultural usersto be organized coherently into an integrated structure. ${ }^{30}$ According to this conception, IWRM's principles and guidelines can be construed as sectoral paradigms for resources management that must themselves be integrated at the operational level. This reflects the fact that IWRM's principles and guidelines originated primarily outside the water sector and tend to contribute to challenges that hinder improved water management when considered in isolation. For example, market-based allocation is impeded by transaction costs and generates externalities, whereas science-based frameworks approximate reality and neglect cumulative impacts, and so on. By themselves, these approaches are not drivers of integration per se.

Through IWRM's integrative dimension, sectoral approaches rely on each other to minimize their respective shortcomings. For example, through integration, the principle of cost-internalization takes into account the finite nature of freshwater resources and forces the development of mechanisms responding to failures of traditional economic approaches entailing externalities and of environmental resources degradation. Participation, precaution, and prevention offer decision-making mechanisms in situations of uncertainty that respond in part to the fail-

28. Malin Falkenmark et al., Towards Integrated Catchment Management: Increasing the Dialogue between Scientists, Policy-Makers and Stakeholders, 20 InT'L J. WAter Resources Dev. 297, 305 (2004).

29. This is notably the case from a purely technical perspective. See Yuqiong Liu et al., Linking Science with Environmental Decision Making: Experiences from an Integrated Modeling Approach to Supporting Sustainable Water Resources Management, 23 ENVTL. Modelling \& SOFtwARE 846, 848 (2008); Peter van der Keur et al., Identification of Major Sources of Uncertainty in Current IWRM Practice, Illustrated for the Rhine Basin, 22 Water Resources Mgmt. $1677,1682-88$ (2008)

30. See Neil S. Grigg, Integrated Water Resources Management: Balancing Views and Improving Practice, 33 WATER INT'L 279, 281 (2008). Echoes of IWRM's core reliance on integration are expressed through abundant references to related notions such as "holistic," "systemic," and "comprehensive." See also Sarah Hendry, Integrated Water Resource Management: Comparative Frameworks for Reform, 17 WATER L. REv. 47, 58-60 (2006) (showing how a reforming process guided by IWRM impacts legal frameworks). 
ure of scientific approaches to produce stable and self-sufficient rational management frameworks. ${ }^{31}$ Particular emphasis must be placed on adapting these principles to local realities and constraints to avoid inconsistencies and discrepancies leading to further fragmentation rather than integration. $^{32}$

\section{B. Defining the HRBA to Water: Going Beyond the Rhetoric? ${ }^{33}$}

The HRBA to development results from a merger of the fields of human rights and international development. ${ }^{34}$ At the theoretical level, the HRBA can be defined as a conceptual framework for human development based on international human rights standards. The HRBA is directed at promoting and protecting human rights. ${ }^{35}$ In other words, the HRBA puts human rights at the very heart of development, including the U.N.'s reform and development work, which has relied on the HRBA since $1997 .{ }^{36}$ At the practical level, the HRBA is open to a large range of interpretations, methodologies, and practices among different U.N. agencies, other multilateral institutions such as the World Bank, and international nongovernmental organizations. ${ }^{37}$ While this blurs the contours of the HRBA to some degree, efforts to provide a sound foundation for the approach have resulted in the following definition: "The central goal of Development has and will be the promotion of human well-being. Given that human rights define and defend human well-being, a

31. Ken Conca, Governing Water: Contentious Transnational Politics and Global Institution BuILding 158 (2006) (identifying the tension within IWRM between participation and expert scientific and rational decision-making for resource optimization). However, because of the predominance of the technocratic planning pole, participation does not generally act as a palliative for the failures of rational management, but instead remains confined to a peripheral principle. See Frances Cleaver, Paradoxes of Participation: Questioning Participatory Approaches to Development, 11 J. INT'L Dev. 597 (1999).

32. See Int'l Water Mgmt. Inst., supra note 19; Bruce Lankford \& Nick Hepworth, The Cathedral and the Bazaar: Monocentric and Polycentric River Basin Management, 3 WATER ALTERNATIVES 82, 85-95 (2010); Bruce Lankford et al., Entrenched Views or Insufficient Science? Contested Causes and Solutions for Water Allocation; Insights from the Great Ruaha River Basin, Tanzania, 69 Agric. Water Mgmt. 135, 148 (2004).

33. Peter Uvin, Human Rights and Development 127 (2004) (noting the danger of rhetorical fluff and repackaging with respect to the HRBA).

34. For an intellectual genealogy of the merger between the two fields, see Peter Uvin, From the Right to Development to the Rights-Based Approach: How "Human Rights" Entered Development, 17 Dev. in Prac. 597, 597-605 (2007).

35. World Health Org., Right to Water 10 (2003).

36. See Emilie Filmer-Wilson, The Human Rights-Based Approach to Development: The Right to Water, 23 Neth. Q. Human Rights 213, 215-16 (2005).

37. For an overview, see Andrea Cornwall \& Celestine Nyamu-Musembi, Putting the "Rights-Based Approach" to Development in Perspective, 25 THIRD World Q. 1415, 1425-35 (2004). 
rights-based approach to development provides both the conceptual and practical framework for the realization of human rights through development process." 38

Conceptually, human rights define the development objectives of the HRBA. However, human rights also determine developmental processes and operational programs for the implementation of the HRBA. $^{39}$ In 2003, a memorandum for a common understanding of the HRBA among many U.N. agencies was articulated, based on the following principles:

(1) All programms of development co-operation, policies and technical assistance should further the realization of human rights as laid down in the Universal Declaration of Human Rights and other international human rights instruments.

(2) Human rights standards contained in, and principles derived from, the Universal Declaration of Human Rights and other international human rights instruments guide all development cooperation and programming in all sectors and in all phases of the programming process.

(3) Development cooperation contributes to the development of the capacities of "duty-bearers" to meet their obligations and/or of "rights-holders" to claim their rights. ${ }^{40}$

Notably, these principles emphasize the importance of standards and assign a guiding role to any human right contained in any type of international human rights instrument. Other central principles linked to the HRBA are "universality and inalienability; indivisibility; interdependence and inter-relatedness; non-discrimination and equality; participation and inclusion; accountability and the rule of law." ${ }^{\text {11 }}$ Relying on these principles, the HRBA is argued to foster development through the fol-

38. See Jason Keeler, United Nations Development Programme, in Review Digest: RightsBased Aprroaches to Development 54, 54 (Sarah Bania-Dobyns et al. eds., 2006), available at http://www.du.edu/korbel/hrhw/digest/development/undp.pdf.

39. See Urban Jonsson, A Human Rights-Based Approach to Programming, in ReINVENTING Development?: Translating Rights-Based Approaches from Theory into Practice 47, 49 (Paul Gready \& Jonathan Ensor eds., 2005).

40. See generally Memorandum from the United Nations, The Human Rights Based Approach to Development Cooperation Towards a Common Understanding Among U.N. Agencies, United Nations Dev. Group, http://www.undg.org/archive_docs/6959-The _Human_Rights_Based_Approach_to_Development_Cooperation_Towards_a_Common_ Understanding_among_UN.pdf [hereinafter U.N. Human Rights Based Approach to Development] (last visited July 27, 2010).

41. Id. A synthetic explanation of these principles is provided by LAURE-HÉlÈnE PirON \& Tammie O'Neil, Overseas Dev. Inst., Integrating Human Rights into Development: A SyNthesis of Donor Approaches AND Experiences 23-24 (2005), available at http:/ www. odi.org.uk/resources/download/3364-full-report.pdf. 
lowing four interrelated aspects: (1) "the direct, indirect, and strategic use of the law"; (2) the refocus on the state as an actor of development; (3) the increase in accountability and the bolstering of capacity building; and (4) the re-politicizing of development by moving away from benevolence. ${ }^{42}$

Thus, the HRBA is an approach to development that uses human rights as justifications and guidelines as well as standards and benchmarks for development. Yet the HRBA is distinct from the human rights on which it is based. However, an analysis of the HRBA is inseparable from a reflection about the impact of human rights on resources management because human rights determine both the approach's substance and form. ${ }^{43}$ A specific focus on the HRBA to development in the water sector converges on the human rights that may serve as claims to water resources (such as the right to health), and excludes irrelevant human rights (such as the right to be free from arbitrary arrest, detention, or exile). ${ }^{44}$ As one scholar noted in regard to the impact of the HRBA on the water sector: "[T] he human rights-based approach commits all water management systems towards the guarantee of the basic need for water and provides the single water user with the instruments to enforce this interest. Hence, it has a twofold purpose: enforcement tool for individuals and political concept of allocation."

42. See Paul Gready, Rights-Based Approaches to Development: What Is the Added Value?, 18 Dev. IN Prac. 735 (2008); Kerstin Mechlem, Food Security and the Right to Food in the Discourse of the United Nations, 10 EuR. L.J. 631, 645-47 (2004) (identifying a dignity dimension, an acknowledgement dimension, a transparency dimension, an accountability dimension, and an empowerment dimension as specific characteristics of the HRBA).

43. According to UvIN, supra note 33, at 122, "[t]he boundaries between human rights and development disappear, and both become conceptually and operationally inseparable parts of the same processes of social change." Anna Russells, International Organizations and Human Rights: Realizing, Resisting or Repackaging the Right to Water?, 9 J. Hum. RTs. 1, 16 (2010), argues that international human rights must be even more closely integrated in the HRBA than they are under current practice.

44. For an overview of the human rights that justify claims on water resources, see Part III.E, and, in particular, infra notes 112-116. See also United Nations, Econ. \& Soc. Council, Comm. on Relationship Between the Enjoyment of Economic, Social and Cultural Rights and the Promotion of the Realization of the Right to Drinking Water Supply and Sanitation, Preliminary Report submitted by Mr. El Hadji Guissé, U.N. Doc. E/CN.4/ Sub.2/2002/10, at 8 (June 25, 2002) [hereinafter Guissé]. One of the central arguments of this article deals with the fact that, under its current definition, and because of the issues discussed in Part III.E below, the HRBA must be associated to access to water for personal basic needs as well as for commercial, industrial or agricultural activities. The HRBA is fully expansive and inconsistencies resulting from this dynamic must be resolved through integration.

45. Knut Bourquain, Freshwater Access from a Human Rights Perspective: A Challenge to International Water and Human Rights Law 12 (2008). This two-fold 
The application of the HRBA in the water sector has been discussed extensively, especially in regard to the added value such an approach can bring. ${ }^{46}$ Expected benefits are numerous and include: ensuring consistency and coherency of the normative framework for management in the water sector; increasing the accountability and transparency of service providers in the water sector; strengthening participation mechanisms to decision-making in water management; prioritizing poor, marginalized, and vulnerable groups; emphasizing legal entitlement and strengthening claims for improved access to water; facilitating partner-donor alignment in the water sector; providing a comprehensive set of minimum standards for water supply; completing the simplistic water sector objectives set by the Millennium Development Goals; ${ }^{47}$ providing a template for water sector reform processes; providing effective monitoring and assessment mechanisms; and making access to water a political priority at the international and national levels.

Despite the HRBA, a global water crisis remains. In many countries, the majority of people still lack access to safe drinking water. ${ }^{48}$ An estimated 260,000 people per day must gain access to improved water sources from 2005 until 2015 in order to meet the U.N. Millennium Development Goals. ${ }^{49}$

purpose corresponds to the effect of the HRBA on national legal frameworks discussed in Parts IV.A and IV.B.

46. See, e.g., Emilie Filmer-Wilson, supra note 36, at 214-20; ThOMAs LeVin, Mijako Nierenköther \& Nina Odenwälder, Human Right to Water and Sanitation: Translating Theory into Practice 12-13 (2009); Inga Winkler, A Human Rights-Based Approach to Water Supply and Sanitation 14-15 (UNDP Policy Guidance Workshop, The Human Right to Water and Sanitation "Translating Theory into Practice," Background Paper 2008); THE Human Rights-Based Approach to Water and Sanitation, The Right to Water and SANITATION, http://www.righttowater.info/the-human-rights-based-approach-to-develop ment-and-implications-for-fieldwork-in-water-and-sanitation (last visited July 27, 2010).

47. See United Nations Millennium Declaration, U.N. GAOR, 55th Sess., 8th plen. mtg., Sept. 18, 2000, U.N. Doc. A/RES/55/2, at 5 (Sept. 18, 2000); U.N. Secretary-General, Road Map Towards the Implementation of the United Nations Millennium Declaration: Rep. of the Secretary-General, IIII 91-92, Annex 55, 57, U.N. Doc. A/56/326 (Sept. 6, 2001).

48. See World Health Org. \& United Nations Children's Fund, Progress on SaniTATION AND DRINKING-WATER: 2010 Update 7 (2010). The 2009 humanitarian crisis and cholera epidemic in Zimbabwe, which was notably caused by a lack of access to clean water and sanitation facilities, provides a stark example of the pressing need in this respect. See Doctors Without Borders, Beyond Cholera: Zimbabwe's Worsening Crisis 1 (2009), http://doctorswithoutborders.org/publications/reports/2009/msf_beyond-cholera_zimb abwes-worsening-crisis.pdf.

49. World Health Org., Celebrating Water for Life: The International Decade FOR ACTION 2005-2015 20 (2005), http://www.who.int/water_sanitation_health/2005advo cacyguide.pdf. Population forecasts suggest that an additional 784 million people worldwide must gain access to improved drinking water sources to meet the commitments of the international community by 2015. See World Health Org. \& United Nations Children's 


\section{INTERACTIONS BETWEEN IWRM AND THE HRBA TO WATER: POTENTIAL TENSIONS}

IWRM and the HRBA to water display many similarities. Both foster participation and share a number of common goals and objectives. In particular, they are both guided by concerns for equity and inclusion, and they both rely heavily on policies and legislation, institutional frameworks, and governance mechanisms. However, inconsistencies between them must be acknowledged in order to resolve potential conflicts and suggest a unified perspective to accord IWRM and the HRBA to water.

Because integration is the core principle of IWRM, the objective of this Part centers on integrating the various aspects of the HRBA, both internally and within a wider context. Doing so does not discount the value of the HRBA as a management paradigm; rather, it identifies conceptual misunderstandings or specific incarnations of the approach that should be streamlined in order to avoid inconsistencies and challenges in implementation. ${ }^{50}$

Five points of tension are explored below. For the most part, they result from the interaction between IWRM's function as an integrating principle versus the HRBA's role as a vehicle for developmental aspirations. For each of these points, questions are raised that should be addressed by resource management frameworks at the operational level in order to harmonize the two approaches and foster adequate water governance.

Fund Joint Monitoring Programme for Water Supply and Sanitation, Progress on Drinking Water and Sanitation: Special Focus on Sanitation 24 (2008). See also P.B. Anand, Millennium Development Goal 7: An Assessment of Progress With Respect to Water and Sanitation: Legacy, Synergy, Complacency or Policy? (United Nations University World Institute for Development Economics Research, Research Paper No. 2006/01 1, 2006) (predicting that "[i]t is highly unlikely that the development target of halving the proportion of people not having access to adequate sanitation will be achieved."). This prediction is now recognized as probably accurate. See U.N. Dep't of Int'l Econ. \& Soc. Affairs, The MiLLeNNiUm Development Goals Report 2010, at 60-62, U.N. Sales No. E.10.I.7 (2010). Moreover, some studies argue that global access to drinking water could decline from 2010 onward despite widespread agreement that the drinking water MDGs (Millennium Development Goals) target will be reached and possibly exceeded. See JosEPHINE FOGDEN \& GEOFfrey Wood, Access to Safe Drinking Water and Its Impact on Global Economic GROWTH 10 (2009).

50. Part IV.C provides a perspective on the result of this endeavor. 


\section{A. The HRBA as an Anthropocentric Tool vs. a Sustainable Ecosystem Management}

As the HRBA strives for the realization of human rights, the implications of human rights-based resources development must be examined. First, human rights are commonly portrayed as anthropocentric. ${ }^{51}$ Through claims to resources essential for human wellbeing, human rights generate a structure designed to foster individual independence, autonomy, and freedom from both social constraints and material adversity. ${ }^{52}$ The abstract sphere of autonomy created by the aggregation of human rights centered on and subservient to individuals aims at guaranteeing the availability of a certain amount of resources for personal satisfaction when and where needed. ${ }^{53}$ This structure entails the emergence of an artificial landscape of claimable resources and social in-

51. According to the World Conference of Human Rights, June 14-25, 1993, Vienna Declaration and Programme of Action, U.N. Doc. A/CONF.157/23 (July 12, 1993), "the human person is the central subject of human rights and fundamental freedoms, and consequently should be the principal beneficiary." This issue is often discussed in the context of an environmental human right. According to Michael Anderson, Human Rights Approaches to Environmental Protection: An Overview, in Human Rights Approaches to Environmental Protection 1, 3 (Alan Boyle \& Michael Anderson, eds., 1996), "environmentalists may suspect that there is a structural contradiction between fulfilling existing rights for a growing population and effective protection of limited environmental goods." On this issue, see also Dinah Shelton, Human Rights, Environmental Rights, and the Right to Environment, 28 STAN. J. INT'L L. 103, 107-109 (1991), and Francesco Francioni, International Human Rights in an Environmental Horizon, 21 EuR. J. INT'L L. 41, 50 (2010). These considerations are particularly relevant because the human right to a clean environment can provide a basis for claims to water. See Salman M.A. Salman, Evolution and Context of International Water Resources Law, in Les Ressources en Eau et le Droit International 79 (Laurence Boisson de Chazournes \& Salman M.A. Salman, eds., 2005). However, it must be noted that the existence of a human right to a clean environment in international law is highly uncertain. See Ghünter Handl, Human Rights and Protection of the Environment, in ECONOMIC, SOCIAL AND Cultural Rights 303 (Asbjrn Eide, Catarina Krause \& Allan Rosas, eds., 2d ed. 2001).

52. See John Merrills, Environmental Rights, in The Oxford HANDBOOK OF InTERnAtional EnVironmental Law 663, 666 (Daniel Bodansky, Jutta Brunnée \& Ellen Hey, eds., 2007).

53. A recent decision by the Supreme Court of Canada refers to this idea when writing that, "[t]he holder of a right has a sphere of autonomy in exercising that right." Ciment du St-Laurent Inc. v. Barrette [2008] 3 S.C.R. 392 (Can.), paras 24, 29. This idea is also captured by H.L.A. Hart's depiction of right-holders as "small-scale sovereigns." See Jenny Grönwall, Access to Water: Rights, Obligations and the Bangalore Situation 133 (May 2008) (unpublished doctoral thesis, Lingköping University) (on file with author). With respect to the material prerequisites enabling individual autonomy, see Peter Jones, Rights 157 (1994). 
teractions superimposed upon, but disconnected from, the existing constraints of the physical and social environments. ${ }^{54}$

This phenomenon includes the realization of the human rights underpinning the HRBA to development within the water sector. ${ }^{55}$ This phenomenon has been studied in great detail with respect to the right to property, which illustrates the generic process of abstraction from contextual limitations stemming from the expression of human rights. ${ }^{56}$ The right to property is directly linked to claims aimed at securing water to satisfy basic human needs in relation to human rights. ${ }^{57}$ Property rightsbased resource allocation systems clash with effective ecosystem management over the long term because ecosystems are ever-changing and unpredictable. ${ }^{58}$ Ecosystem dynamics do not correspond to the requirements of certainty and standardization underlying property law that are needed to facilitate socioeconomic transactions. Thus, in the context of

54. On the disconnection from constraints, see Prue Taylor, Ecological Integrity and Human Rights, in Reconciling Human Existence with ECOlOGical InTEgrity 89 (Laura Westra, Klaus Bosselmann \& Richard Westra, eds., 2008).

55. The HRBA is based on "an essentially human-centred view as it promotes water as a social resource" but one in which environmental considerations should also be included. John Scanlon, Angela Cassar \& Noémie Nemes, Water as a Human Right? 33 (Environmental Policy and Law Paper No. 51, 2004), available at http://data.iucn.org/dbtw-wpd/ edocs/EPLP-051.pdf. See also Karen Assaf, Bayoumi Attia, Ali Darwish, Batir Wardam \& SiMONE KLAWITTER, Water as a Human Right: The Understanding of Water in the Arab Countries of the Middle East-A Four Country Analysis 26 (Heinrich Böll Foundation, Global Issue Paper No. 11, 2004).

56. There is a traditional tension between human rights and the right to property. See Catarina Krause, The Right to Property, in Economic, Social and Cultural Rights 191 (Asbjrn Eide, Catarina Krause \& Allan Rosas, eds., 2d ed. 2001). Nevertheless, the right to property cannot be excluded from the realm of human rights. Firstly, it is recognized in some international human rights law instruments. See Organization of American States, American Convention on Human Rights, art. 21, July 18, 1978, O.A.S.T.S. No. 361144 U.N.T.S. 123 [hereinafter American States]; Universal Declaration of Human Rights, G.A. Res. 217 (III) A, U.N. Doc. A/RES/217(III) art. 17, at 71 (Dec. 10, 1948). Secondly, property is constitutionally protected as a human right in many national jurisdictions: For example, the Fourteenth Amendment to the U.S. Constitution prohibits the states from depriving "any person of life, liberty and property without due process of law." Thirdly, at least some doctrine argues that property is a human right. See Realizing Property Rights, Swiss Human Rights Book (Hernando de Soto \& Francis Cheneval, eds., vol. 1, 2006). In this context, statements that exclude the right to property from the human rights included under the HRBA as defined in the U.N. Human Rights Based Approach to Development, supra note 40, appear incoherent.

57. See, e.g., Zander v. Sweden (No 14282/88), 279a Eur. Ct. H.R. (ser. A) at 38 (1993), in which the right to property under article 6 (1) of the European Convention on Human Rights justifies a claim concerned with the potential pollution of a drinking water well by a nearby landfill.

58. See generally Lynda L. Butler, The Pathology of Property Norms: Living Within Nature's Boundaries, 73 S. CAL. L. Rev. 927, 936 (2000). 
water resources management, the connection between humans and an actual physical space has gradually been eroded by making property a universal abstraction rather than a situation-dependent entitlement. ${ }^{59}$ In order to respond to this issue, the redefinition of property rights over water resources should be reexamined, including limiting these rights to specific uses and locations and tailoring them to recognize ecological dependencies and avoid negative social impacts. ${ }^{60}$

In order to integrate the HRBA within physical and social constraints, some questions should be addressed by water management frameworks. For example, when defined as a standardized individual claim to water in sufficient quantity and quality for the satisfaction of basic human needs, does the formulation-a fortior ${ }^{61}$ the implementation-of a right to water negate fundamental underlying contextual relationships at the social and environmental levels? Can a person decide to reside in the middle of a desert and then claim water resources from the state on the basis of human rights? ${ }^{62}$ Are there specific locations or situa-

59. See generally A. Dan Tarlock, Reconnecting Property Rights to Watersheds, 25 WM. \& Mary Envtl. L. \& Pol'y Rev. 69, 72 (2000). In addition to eroding the connection between the title-holder and the environment, formalizing ownership and collapsing rights into the individual also severs contextual social webs and negates traditional structures serving as conduits for the excluded. See Ruth Meinzen-Dick \& Ester Mwangi, Cutting the Web of Interests: Pitfalls of Formalizing Property Rights, 26 LAND USE POL'y 36, 37-38 (2008).

60. See generally Lee Breckenridge, Can Fish Own Water?: Envisioning Nonhuman Property in Ecosystems, 20 LAND UsE \& ENVTL. L. 293, 295 (2005); Peter Laban, Accountability and Rights in Right-Based Approaches for Local Water Governance, 23 INT'L J. WATER RESOURCES Dev. 355, 357 (2007).

61. A fortiori means "by even greater force of logic; even more so." BLACK's LAW DiCTIONARY 69 (9th ed. 2009).

62. Some statements regarding the consequences of human rights on access to water warrant caution. See, e.g., Guissé, supra note 44, at II 24 (stating, "[t]he access of everyone to safe drinking water must be an imprescriptible right. It must not be subject to any restriction, in any place or at any time."); David Bilchitz, Poverty and Fundamental Rights: The Justification AND ENFORCEMENT of Socio-Economic Rights 96 (2007) (noting that "it seems unfair to guarantee all individuals the same level of provision regardless of whether they landed up in a needy position as a result of their own choices or not. Ensuring that individuals are able to realize their rights is not costless and places burdens on other members of society. By making reckless choices that imperil their rights, individuals shift the burden of providing for their needs from themselves to other members of the society. A greater amount of societal resources would then have to be spent on providing for the reckless individuals than if they had provided for themselves. That, in turn, entails that greater burdens are placed upon other 'prudent' members of society as a result of the choices of reckless individuals. To allow such a situation to obtain would be to allow individuals to determine the distribution of resources in a society according to their own choices. Yet to do so could in fact violate the principle of equal importance that, amongst other things, requires that the benefits and burden in a society fall equally upon each individual.") 
tions where it is not possible to claim water based on human rights in order to drink, cook, grow crops, or raise cattle? If so, how can these rights be identified and delineated?

\section{B. The HRBA to Foster Development vs. Water Resources as a Limit to Growth $^{63}$}

The HRBA to development in the water sector has an important, underlying economic aspect. ${ }^{64}$ Universally claimable human rights seem to have at their core a minimum level of economic development, including the exploitation of natural resources that must increase with population growth. ${ }^{65}$ Because it does not suggest intrinsic limits to potential increases in the number of right-holders, the HRBA to development implies an infinite resource basis. Human rights doctrine does recognize that limits to state resources are potential constraints on the realization of human rights. However, this does not imply that the human rights doctrine or the HRBA to development internalize absolute limits to natural resource exploitation and economic development. In some conceptions of the relationship between the realization of human rights and drinking water supply and sanitation, development is geared toward the Western

63. This issue is closely related to the discussion in Part III.A regarding anthropocentrism. However, whereas Part III.A explores the potential dissociation of standardized claims justified under the HRBA from contingencies related to water resources at an individual level, the question discussed in Part III.B examines the tension between an HRBA approach to development and the resource basis in a global context.

64. See U.N. Development Programme, Human Development Report 2000, 8, 80 (2000); JAmes Nickel, Making Sense of Human Rights 79 (2d ed., 2007) (discussing costs, feasibility and the operative character of rights). The link between a human rights-based access to water and economic resources is recognized. See Antonio Irujo, The Right to Water, 23 Int'L J. Water Resources Dev. 267, 281-82 (2007). Stephen McCaffrey \& Kate Neville, Small Capacity and Big Responsibilities: Financial and Legal Implications of a Human Right to Water for Developing Countries, 21 Georgetown Int'L EnvtL. L. Rev. 679, 681-86 (2009), emphasize that immediate fulfillment of the core minimum obligations of a human right to water is a very onerous burden. Asit K. Biswas, Water as a Human Right in the MENA Region: Challenges and Opportunities, in Water as a Human Right FOR the Middle EAst AND North Africa 1, 7 (Asit Biswas, Egal Rached \& Cecilia Tortajada, eds., 2008) suggests that some states are reluctant to acknowledge the human right to water because of a lack of resources.

65. Regarding the minimum core, see United Nations, Econ. \& Soc. Council, Comm. on Economic, Social and Cultural Rights, 55th Sess., Supp. No. 3, Nov. 26-Dec. 14, 1990, U.N. Doc. E/1991/23, at 86 (1991); United Nations, Econ. \& Soc. Council, Comm. on Econ., Social and Cultural Rights, Substantive Issues Arising from the Implementation of the International Covenant on Economic, Social and Cultural Rights, General Comment No. 15, 29th Sess. Nov. 11-29, 2002, II 37, U.N. Doc. E/C.12/2002/11, at 12-13 (Jan. 20, 2003) (identifying the minimum core regarding the human right to water) [hereinafter General Comment 15]. 
socioeconomic model, and no country is portrayed as too developed or too wealthy. ${ }^{66}$

This aspect of the HRBA to development in water fails to acknowledge the finite nature of renewable freshwater resources. The world's freshwater potential is estimated at $90,000 \mathrm{~km}^{3} /$ year, with only $12,000 \mathrm{~km}^{3}$ /year theoretically accessible under ideal conditions. ${ }^{67}$ Finite water resources imply limits to the amount of water available for human needs (such as drinking, nourishment, and sanitation) as well as limits to economic and industrial development. ${ }^{68}$ Human use of water resources is already close to its supply limit in many cases, with total human water withdrawals expected to reach a barrier point in many countries over the next 20 years. ${ }^{69}$ The potentially antagonistic dynamic between water for

66. See Pooja Parmar, Revisiting the Human Right to Water, 28 Austl. Feminist L.J. 77, 87-90 (2008). See Guissé, supra note 44, at III 8, 14, 17-18, 47 \& 48, stressing the importance of increased agricultural and industrial development at the global level to ensure access to drinking water. Presumably, differences in levels of development cannot be presented as irremediable lest they sap the justification and legitimacy of developmental efforts.

67. Maria Saleth \& Ariel Dinar, The Institutional Economics of Water: A CrossCountry AnAlysis of Institutions AND Performance 2 (2004). These estimates vary depending on the source. See, e.g., H.L.F. Saeijs \& M.J. van Berkel, The Global Water Crisis: The Major Issue of the Twenty-first Century, a Growing and Explosive Problem, in THE SCARCITY OF Water: Emerging Legal and Policy Responses 3, 5-6 (Edward Brans et al. eds., 1997). Saeijs \& van Berkel's assessment seems to overestimate the total amount available for human consumption, as no provision is made for environmental flows on which ecosystems and dependant communities rely for survival.

68. In the general context of the HRBA, the volumes of water required for drinking and sanitation are dwarfed by the quantities used to produce food, especially given the increasing prevalence of the Western food diet. See Frank Rijsberman \& David Molden, Balancing Water Uses: Water for Food and Water for Nature (Thematic Background Paper presented at the International Conference on Freshwater, Dec. 3-7, 2001), http://www. riverbasin.org/newsmaster.cfm? \&menuid=113\&action=view\&retrieveid=705. On a global scale, the amounts required for human needs related to food are far from negligible from an environmental point of view and may ultimately lead to devastating ramifications. Frank Rijsberman, Water Scarcity: Fact or Fiction?, 80 AGRIC. WATER MGMT. 5, 12-14 (2006).

69. SAlETH \& DiNAR, supra note 67 , at $4-5$. On the issue of limits to natural resources exploitation and economic development, see Gretchen C. Daily, Developing a Scientific Basis for Managing Earth's Life Support Systems, 3 Conservation ECOlogY, No.2, 14 (1999) (explaining that "escape from local resource constraints is, by definition, temporary in a world in which population and per capita consumption are growing. The projected rapid global increase in demand for food, fresh water, energy, and other resources over the next few decades implies a world much closer to, and more places in excess of, such limits" (internal citation omitted)). For a global overview of limits to growth with respect to water resources, see Donella Meadows, Jorgen Randers \& Dennis Meadows, Limits to Growth, The 30-YeAR Update 66-74 (2004). Note that the figures in this publication correspond to the maximum amount of water annually available as identified by SALETH \& DINAR, supra note 67. 
human consumption and a sustainable environment results in the following:

Social and economic development necessitates the utilization of, and thus impact on, natural systems. This modification of natural systems results in a trade-off between the additional (artificial) benefits gained and those which are lost as human adjustment negatively impacts ... some natural functions, and this undermines the benefits of natural services provided to society. Where ecosystems are over exploited, their ability to provide these goods and services is lost. ${ }^{70}$

Human water resources utilization, if continued under a businessas-usual scenario, will result in the "inevitable degradation or complete destruction of the terrestrial freshwater and coastal ecosystems that are vital to life itself." ${ }^{, 71}$ Moreover, restoration of these natural ecosystems is generally quite expensive and produces outputs inferior to the natural ones. ${ }^{72}$ From water's finite resources perspective, the principles of precaution and prevention conflict with the HRBA unlimited resources approach.

To integrate the physical limits of water resources into the HRBA, several questions should be addressed by water management frameworks. Are there limitations to the satisfaction of basic human needs? ${ }^{73}$ Should this imply limits to claims based on human rights?

70. Graham Jewitt, Can Integrated Water Resources Management Sustain the Provision of Ecosystem Goods and Services?, 27 Physics And Chemistry of the Earth 887, 888 (2002); see also World Health Org., Millennium Ecosystem Assessment, Ecosystems and Human Well-Being: Health Synthesis (2005).

71. Rijsberman \& Molden, supra note 68, at 5 (citing InTERnational UniON FOR the Conservation of Nature, Vision for Water and Nature: A World Strategy for ConServation and Sustainable Management of Water Resources in the 21st Century (2000)).

72. See Carmen Revenga, Conditions and Trends of Freshwater Ecosystems and the Challenges to Meet Human Water Needs, in WATER AND Ecosystems: MANAGing WATER IN Diverse Ecosystems to Ensure Human Well-Being 1, 4 (Caroline King et al. eds., 2007); Millennium Ecosystem Assessment, Ecosystems and Human Well-Being: Wetlands and Water SYNTHESIS 46-49 (2005).

73. See Max Finlayson, Wetland Ecosystems and Human Needs-Balancing the Water Needs of Ecosystems with Those for People and Agriculture, in WATER AND Ecosystems, supra note 72 , at 23. From the HRBA point of view, a traditional answer to this argument is that water consumption for basic human needs is negligible. See Malcom Langford, Ambition that Overleaps Itself? A Response to Stephen Tully's Critique of the General Comment on the Right to Water, 24 Neth. Q. Hum. Rts. 433, 455-56 (2006). It is clear that claims to water for food production justify the majority of anthropogenic water uses, and a priori serve to fulfill the right to food. See supra note 68 and infra note 113. However, based on the HRBA, it remains unclear which water volumes allocated to food production are superfluous, i.e., what part 
Should environmental uses be prioritized over human water usage? Conversely, is the protection of residual environmental flow (i.e., the prioritization of "the environment's water right") an impediment to development and to the satisfaction of human needs? Should reflections on the human-rights based access to water be influenced by considerations related to the capacity of the environment to sustain human impacts at the global, regional, and local levels? What do these considerations imply for a contextual approach to the definition of human rights? ${ }^{74}$ When does a human need become superfluous? Is there a limit to development, and if so, has it been overshot in some cases? ${ }^{75}$ Does development of the poorest imply a reduction in the level of development of the richest? ${ }^{76}$

\section{The HRBA to Drinking Water and Sanitation vs. the User-Pays Principle}

Human excreta are the inescapable by-product of food and water consumption necessary for survival. Unless treated through environmental purification or artificial processes, human excreta are a significant source of contamination that degrade water quality and pose a threat to health. According to the World Health Organization:

The great majority of evident water-related health problems are the result of microbial (bacteriological, viral, protozoan or other biological) contamination. ... In general terms, the greatest microbial risks are associated with ingestion of water that is contaminated with human or animal (including bird) faeces. Faeces can be a source of pathogenic bacteria, viruses, protozoa and helminths. Faecally derived pathogens are the

of current global food production is excessive and should be curtailed. For projections on the tensions stemming from the water requirements to feed humanity by 2050, see MALIN FAlKenMark \& Johan Rockström, Balancing WATER fOR Humans and Nature 60-63 (2004)

74. For a critique of the contextual definition of socioeconomic rights, see JonEs, supra note 53 , at $157-64$.

75. Unsustainable development through over-allocation of water is obvious in certain cases. In the Murray-Darling river basin, the Australian government has earmarked AU\$3.1 billion to purchase water from license holders in order to ensure environmental flows and limit environmental damages. See Australian Government Department of the Environment, Water, Heritage and the Arts, Water For the Future: Fact Sheet (Jan. 2010), http://www.environment.gov.au/water/publications/mdb/pubs/restoring-balance.pdf.

76. Some of these questions have been considered by proponents of environmental ethics. See Holmes Rolston III, Feeding People versus Saving Nature, in EnVIRONMENTAL EthICS 451, 460 (Andrew Light \& Holmes Rolston III eds., 2003). 
principal concerns in setting health-based targets for microbial safety. ${ }^{77}$

In this context, the satisfaction of humankind's most basic needs is also humankind's most basic negative environmental externality. This interaction between human rights to water and human excreta must be addressed, especially in the current model of development that entails urbanization, waterborne sanitation, and unitary sewers. ${ }^{78} \mathrm{~A}$ fragmented view of water management, focusing exclusively on providing water for basic human needs, would characterize wastewater, excreta, and greywater as costly by-products requiring substantial investments in treatment plants and disposal mechanisms. ${ }^{79}$ Because some conceptions of the HRBA define the individual as a right-holder and creditor of obligations without compensation, this approach might externalize the costs of subsistence in contradiction with the user-pays/polluter-pays principle. ${ }^{80}$

77. 1 World Health OrG., Guidelines for Drinking-Water Quality 3 (3d ed., 2008) (incorporating first and second addenda), available at http://www.who.int/water_sanita tion_health/dwq/fulltext.pdf.

78. Sunita Narain, Why the Flush Toilet Is Ecologically Mindless and Why We Need a Paradigm Shift in Sewage Technology, Address at the Second International Symposium on Ecological Sanitation (Apr. 7-11, 2003), in ECOSAN-CLOSING THE LoOP 13, http://www2. gtz.de/dokumente/bib/04-5004a.pdf; see also Asit Biswas, Water Management for Major Urban Centres, 22 Int'L J. Water Resources Dev. 183, 184 (2006).

79. World Health Org., Guidelines for the Safe Use of Wastewater, Excreta and Greywater: Policy and Regulatory Aspects 1 (2006), http:/ /www.who.int/water_sanita tion_health/wastewater/gsuweg1/en/ index.html (July 27, 2010).

80. Some conceptions of the HRBA establish a dichotomy between right-holders and duty bearers. PIRON \& O'NeIL, supra note 41, at 24 (explaining that "[i]n a HRBA human rights determine the relationship between individuals and groups with valid claims (rights-holders) and State and non-State actors with correlative obligations (duty-bearers)."); see also infra note 107. The existence of these positions must be acknowledged as they generate some of the inconsistencies that this article aims at reconciling. Laban, supra note 60 , at $359-60$, mentions that inadequate focus on the responsibilities of right-holders is indeed a pitfall of the HRBA. This is not to say that all conceptions of the HRBA segregate rights-holders and duty-bearers. Some emphasize that right-holders also bear duties. Jonsson states that

[t]he relationship between rights holders and duty bearers also constitutes a core component of a human rights approach, but most scholars in the area of international human rights law recognize obligations only on the part of the state. There is a need to extend the claim-duty relationships to include all relevant subjects and objects at subnational, community and household levels. . . . Claim holders and duty bearers are not labels applied to specific individuals, but roles that individuals may perform. . . . This system of claim-duty relationships is called the pattern of rights. This pattern must be understood in an HRBAP [Human Rights-Based Approach to Programming]. 
To fully integrate the negative environmental impact that arises from basic human water consumption within the HRBA, several questions should be addressed by water management frameworks. For example, what are the specific duties that right-holders have with respect to the environmental externalities generated by the fulfillment of their rights $?^{81}$ When does the utilization of water for basic human needs actually become a right to pollute or negatively impact the environment? To what extent is the user-pays/polluter-pays principle at odds with the right to water, and a fortiori at odds with the inclusion of sanitation in the right to water ${ }^{82}$ To what extent should the right to water and the right to sanitation be conceived as a single construct rather than antagonistic le-

Jonsson, supra note 39 , at 50. International human rights instruments also recognize rightholders' reciprocal duties to each other and their communities. See, e.g., United Nations, Comm. on Econ., Soc. \& Cultural Rights, International Covenant on Economic, Social and Cultural Rights, Preamble (Dec. 16, 1966). This recognition now filters in the discourse on the human rights-based access to water, although a literature review identifies only one description of the specific details of the duties corresponding to these rights. See CÉLINE Dubreuil, The Right to Water: From Concept to Implementation 11 (2006). With respect to the polluter-pays principle, see United Nations Conference on Environment and Development, Rio de Janeiro, Braz., June 3-14, 1992, Rio Declaration on Environment and Development, Principle 16, U.N. Doc. A/Conf.151/26/Rev.1 (Vol.1), Annex I (Aug. 12, 1992). See generally Philippe Sands, Principles of International Environmental Law 279-81 (2d ed., 2003); Nicolas de Stadeleer, Environmental Principles: From Political Slogans to Legal Rules 42-44 (2002); Peter Rogers, Ramesh Bhatia \& Annette Huber, Global Water Partnership Technical Advisory Committee, Water as a Social and Economic Good: How to Put the Principle into Practice 9 (1998).

81. According to a wide range of sanitation specialists, the right to sanitation "does not define a specific policy or framework for implementation. This needs to be developed by applying the right to prevailing conditions in each country as well as by taking into account technological and other solutions." COHRE, UN-HABITAT, WATERAID \& SDC, SANItATION: A Human Rights Imperative (2008), http://www.unhabitat.org/pmss/getElec tronicVersion.aspx?nr=2927\&alt=1. For a concrete example, in Québec, owners of residences not connected to sewers are legally obliged to bear the costs of treatment systems for their excreta. See Regulation Respecting Waste Water Disposal Systems for Isolated Dwellings, R.R.Q., c. Q-2, r. 8, s. 3 (Can.). Failure to respect regulatory provisions may justify penal sanctions by the state or even third party recourses based on a human right to environment quality. See Environment Quality Act, R.S.Q., c. Q-2, s. 19.1-19.3, 20 (Can.) [hereinafter EQA]; Charter of Human Rights and Freedoms, R.S.Q., c. C-12, s. 46.1 (Can.) [hereinafter CHRF].

82. U.N. Human Rights Council, Promotion and Protection of All Human Rights, Civil, Political, Economic, Social and Cultural Rights, Including the Right to Development: Report of the Independent Expert on the Issue of Human Rights Obligations Related to Access to Safe Drinking Water and Sanitation, U.N. Doc. A/HRC/12/24 (July 1, 2009) [hereinafter U.N. Human Rights Council, Promotion and Protection], recommends recognizing a right to sanitation distinct from other rights. This report expressly acknowledges limits to obligations for dutybearers, the existence of responsibilities for right-holders, and the importance of context in defining sanitation. 
gal artifacts? Indeed, if the environmental impacts of sanitation are linked to the duties of right-holders fulfilling basic human water needs, to what extent can the cost of these impacts also be claimed through a human right? Does harmonization of the polluter-pays principle with the conception of the individual as a rights-holder with respect to personal consumption of water entail the prioritization of one notion over the other? And if so, to what extent and for whom?

\section{The HRBA as a Moral Allocation Framework vs. Economic Management}

Because human rights may be considered antithetical to market efficiency, the relationship between the HRBA and economic management must be explored. ${ }^{83}$ This issue has received extensive commentary and is often depicted as the most obvious point of conflict between the HRBA and IWRM. ${ }^{84}$ Two statements fundamental to the IWRM and the right to water illustrate the tension between water viewed as an economic good versus a social and cultural one: (1) From Principle No. 4 of the Dublin Declaration: "Water has an economic value in all its competing uses and should be recognized as an economic good," 85 and (2) from General Comment 15 on the right to water: "Water should be treated as a social and cultural good, and not primarily as an economic good." 86

This conflict as to whether water should be viewed as an economic good is not ineluctable but depends on the context and characteristics of local governance frameworks. ${ }^{87}$ Although numerous and multifaceted, economic approaches to water management fall under two general categories. ${ }^{88}$ The first category relies on the belief that the effiecient allocation of water resources, measured in economic value, is

83. According to Manuel Couret Branco \& Pedro Damião Henriques, The Political Economy of the Human Right to Water, 42 Rev. of Radical Pol. Econ. 142, 146 (2010), the market is not qualified to promote the human right to water.

84. See, e.g., Henri Smets, Economics of Water Services and the Right to Water, in FresH WAter AND International ECONOMic Law 173, 177-83 (Edith Brown Weiss, Laurence Boisson de Chazournes \& Nathalie Bernasconi-Osterwalder eds., 2005); Antoinette Hildering, Water as an Economic Good, in Les Ressources en EAU ET LE DrOIT INTERNATIONAL, supra note 51, at 209; Erik Bluemel, The Implications of Formulating a Human Right to Water, 31 ECOLOGY L.Q. 957, 963-67 (2004).

85. Dublin Principles, supra note 9.

86. General Comment 15 , supra note 65 , at $5, \S 11$.

87. See Jessica Budds \& Gordon McGranahan, Are the Debates on Water Privatization Missing the Point? Experiences from Africa, Asia and Latin America, 15 EnV'T \& URbanization 87, 94-95 (2003).

88. See generally Luiz Gabriel T. deAzevedo \& Alexandre M. Baltar, Water Pricing Reforms: Issues and Challenges of Implementation, 21 InT'L J. WAter Resources Dev. 19 (2005). 
maximized by markets. ${ }^{89}$ In this instance, economic value serves as an apportionment mechanism among different types of utilization and various users based on marginal costs and benefits. Here, economic value maximizes water's total utility and value to society and therefore increases welfare and development. ${ }^{90}$ The second category recognizes water's economic value based on accounting principles for costs recovery that require the tarification of water and sanitation services to ensure their sustainability. ${ }^{91}$

Both economic approaches may be portrayed as antagonistic to human rights in that they might deny the inalienable access to water and sanitation of the poor and marginalized. In the first category, the denial might stem from the allocation of water to the highest bidder for a more economically valuable use unrelated to basic needs. However, this threat to the human rights-based access to water might not be fully justified, as some water-marketing regimes allow transfers only between the same types of use. ${ }^{92}$ In the second category, the privatization of water and sanitation services is the principal concern, and denial of access to water might be caused by cutting off defaulting customers in order to preserve the economic profitability of the service provider. This perceived threat must also be contextualized. ${ }^{93}$ Self-sustainable services based upon payment by the users are recognized as the aim for both the public and the

89. For a seminal article on this subject, see J.W. Milliman, Water Law and Private Decision Making: A Critique, 2 J.L. \& ECON. 41 (1959).

90. See Terry Anderson \& Pamela Snyder, Water Markets: Priming the Invisible Pump (1997); Ronald Griffin, Water Resource Economics: The Analysis of Scarcity, Policies and Projects (2006).

91. See Am. Water Works Ass'N, Principles of Water Rates, Fees, and Charges (5th ed., 2000).

92. With respect to restrictions on transfers between types of use, see COMMONWEALTH of Australia Productivity Commission, Water Rights Arrangements in Australia and Overseas 192 (2003). Cf. A. Dan Tarlock, Water Transfers: A Means to Achievable Sustainable Water Use, in FRESH WATER AND INTERNATIONAL ECONOMIC LAW, supra note 84, at 35, 41 (mentioning that " $[\mathrm{m}]$ any water rights transfers remove water from agricultural use and dedicate it to urban use."). In this context, economic management raises more questions with respect to balancing a human right to water for domestic use satisfied by urban infrastructures with a human right to food relying on sufficient quantities of water for agricultural irrigation, than it does about access to water for the basic needs of the poor.

93. This is actually an issue that can be solved more easily through a block-tariff structure with free minimal volume. See Hildering, supra note 84, at 223-25; City of Johannesburg v. Mazibuko (489/08) [2009] ZASCA 20. However, such a solution does not resolve more delicate underlying challenges related to the identification and implementation of adequate and effective measures to extend aqueduct networks to the urban poor. Jennifer Davis, Private-Sector Participation in the Water and Sanitation Sector, 30 ANN. REV. OF ENV'T \& Resources 145, 169 (2005). 
private sectors. ${ }^{94}$ Moreover, the private sector's involvement varies from equipment provider (for purification membranes, sewer pipes, etc.) to concession holder, but is never totally excluded in reality. ${ }^{95}$ Thus, economic resources management and human rights-based claims on water resources are not antithetically opposed; in fact, they can coexist without fundamental tensions. For example, guidelines for the realization of the human right to food encompass market forces. ${ }^{96}$ Similarly, the human right to water appears to coexist without exacerbated tensions with economic management in some instances ${ }^{97}$ Hence, claims that application of human rights to water results in free water should be qualified. ${ }^{98}$

94. See, e.g., Michel Camdessus \& James Winpenny, Financing Water for All, RePORT OF THE World PANel on Financing Water Infrastructure 48 (2003), http:/ / www. worldwatercouncil.org/fileadmin/wwc/Library/Publications_and_reports/Camdessus Report.pdf.

95. U.N. Human Rights Council, Promotion and Protection of All Human Rights, Civil, Political, Economic, Social and Cultural Rights, Including the Right to Development: Report of the Independent Expert on the Issue of Human Rights Obligations Related to Access to Safe Drinking Water and Sanitation, at 4-5, U.N. Doc. A/HRC/15/31 (June 29, 2010), provides a typology of private-sector involvement and notes that anxiety over water privatization is exaggerated given that only 5 percent of networks in the world are privately operated.

96. See U.N. Food and Agriculture Organization, Voluntary Guidelines to Support the Progressive Realization of the Right to Adequate Food in the Context of National Food Security, 13-14, §§ 4.1-4.10 (2005), http:/ / www.fao.org/righttofood/publi_01_en.htm. These guidelines do not detail whether realization of the human right to food covers the water component of that right.

97. General Comment 15 , supra note 65 , at $6, \S 12$ (c)(ii) (requiring that direct and indirect costs and charges associated with securing water be affordable and not compromise or threaten the realization of other international human rights); Karen Bakker, The "Commons" Versus the "Commodity": Alter-globalization, Anti-privatization and the Human Right to Water in the Global South, 39 ANTIPODES 430, 438-40 (2007) (noting that the human right to water is conceptually compatible with capitalist political economic systems). Nevertheless, some critiques indicate that the easy coexistence between economic management and human rights-based claims to water resources is in fact the symptom of an underlying capitulation before liberal economic forces. See Radha D'Souza, Liberal Theory, Human Rights and WaterJustice: Back to Square One?, L. Soc. Just. \& Global Dev. J., Oct. 9, 2008, at 9 (noting that

$[\mathrm{w}]$ hat is missed by political theorists canvassing for human rights as a means of mitigating the problems of privatization in the wake of "globalization" is the fact that the struggle for new rights come[s] with recognition of new market prerogatives. The human right to water arises because water is brought into a private property regime in which it was not included before. What is at stake here is the entrenchment of water as part of a property regime.

(emphasis in original)). "Property" refers to a political conception of social and economic regimes, not, strictly speaking, to the legal artifact.

98. For an example of such a claim, see United Nations, Econ. \& Soc. Council, supra note 44 , at 9 . This suggestion is even more relevant in the context of the ineluctable environmental degradations that human activity entails. See discussion supra Part III.C. 
To further harmonize the HRBA with economic management, several questions should be addressed by water management frameworks. For example, should different types of water uses be prioritized? How does market resource allocation, which implies tradable rights, interact with a morally justified right to equitable access to water for domestic purposes, which is typically construed as inherently personal and untradeable? What is the impact on right-holders of the delegation of water management activities by the state as the duty-bearer? Does the recognition of the human rights-based access to water have an impact on nonstate actors? ${ }^{99}$ Is there a tension between affordability and equity on one hand, and the sustainability of water and sanitation services on the other? If such is the case, does this tension reverberate on the relationship between affordability and equity? In this context, is General Comment 15's reconciliation of these two concepts sufficiently robust? ${ }^{100}$ For example, is it possible that a situation where drinking water made affordable to all at present entails an inequitable financial burden for future generations, given the long depreciation periods and investment cycles for water infrastructures? Is there a point where differentiated tariffs in accordance with a right to water conflict with the right to nondiscrimination?

\section{E. The Nebula of the HRBA vs. Certainty and Consistency}

Some suggest that amorphous aspects of human rights generate problems of clarity and consistency that might impair the effectiveness of the HRBA in prospective water resources management. ${ }^{101}$ However, this insufficient certainty and consistency of human rights in the context of

99. See Andrew Clapham, Human Rights Obligations of Non-State Actors (2006); U.N. General Assembly Human Rights Council, Business and Human Rights: Towards Operationalizing the "Protect, Respect and Remedy" Framework, Report of the Special Representative of the Secretary-General on the Issue of Human Rights and Transnational Corporations and Other Business Enterprises, Apr. 22, 2009, U.N. Doc. A/HRC/11/13; U.N. General Assembly, Human Rights Council, U.N. Doc. A/HRC/15/31, supra note 95, at 9; Violeta Petrova, At the Frontiers of the Rush for Blue Gold: Water Privatization and the Right to Water, 31 BROOKLYN INT'L L.J. 577, 582-83 (2005-2006).

100. See General Comment 15, supra note 65, at 6, § 12(c)(ii), $10 \S 27$. Melina Williams, Privatization and the Human Right to Water: Challenges for the New Century, 28 MicH. J. INT'L L. 469, 498 n.202 (2006), reports that "equity is a 'comparative standard' that judges the relative burden on poor and richer households, while affordability 'suggests the right to water sets an upper limit on the cost of water in relation to people's ability to pay for it."' (internal citation omitted).

101. According to Salman M.A. Salman \& Siobhan McInerney-Lankford, The Human Right to Water: Legal and Policy Dimensions 918, at 58 n.217 (2004), "lack of normative clarity . . . leads towards an ambiguous and uncertain practical applicability of the human right to water." (citation omitted). 
the HRBA to development result from three elements, each of which is explored below.

First, the nature of human rights is elusive. ${ }^{102}$ Philosophical debate has raged on this subject at least since the nineteenth century, only to reach a stand-off. ${ }^{103}$ Pure legal positivism has been rejected on innumerable occasions in favor of conceptions of human rights as rhetorical tools for political empowerment, as unquestionable ethical imperatives, and as idealistic necessities. ${ }^{104}$ Attempts to deal with human rights' heterogeneity through unifying theories based on a central justification such as dignity are often portrayed as utopian or unworkable. ${ }^{105}$ The evasive nature of human rights is particularly well-illustrated through the following:

102. See generally Marie-Bénédicte Dembour, What Are Human Rights? Four Schools of Thought, 32 Hum. RTS. Q. 1, 2-4, for a typology of viewpoints on the nature of human rights.

103. A synthetic overview of this debate is provided by Jerome Shestack, The Philosophical Foundations of the Human Rights, in Human Rights: ConCEPTS AND STANDARDS 31 (Janusz Symonides, ed., 2000). The debate does not only focus on the "human" element in "human rights," but also extends to the definition of rights. On this issue, the evolution from Bentham to Hohfeld, Rawls, and Dworkins has arguably resulted in a standoff. L.W. SUMNER, The Moral Foundations of Rights 51 (1987). This philosophical debate cannot be discarded as purely academic, notably because a modified Hohfeldian typology has been used in an empirical analysis to establish that, although it can add to the panoply of policy instruments, a formal human right to water is not essential and has little impact by itself on progress toward MDG targets. See P.B. Anand, Right to Water and Access to Water: An Assessment, 19 J. INT'L Dev. 511, 512 (2007).

104. See, e.g., Jack Donnelly, Universal Human Rights in Theory and Practice 14-16 (2d ed. 2003). Amartya Sen, Human Rights and the Limits of Law, 27 CARdozo L. Rev. 2913, 2915 (2006) (asking "[i]s the practical relevance of human rights entirely parasitic on legislation that has actually occurred? This would be hard to accept.").

105. Dignity is identified as a foundation for the HRBA to freshwater access. See BourQUAIN, supra note 45 , at 61,105 . An example of a systematic human rights framework based on dignity as a foundational super-value is provided by M.S. McDougal, H.D. LAsswell \& L.C. Chen, Human Rights and World Public Order (1980). This approach is criticized by JONES, supra note 53, at 53-54, as having a Western orientation, being difficult to use, having a utopian aspect which belies reality, and resulting in a huge list of demands in which there is no hierarchical order and where both trivial and serious claims are intertwined. Christopher McCrudden, Human Dignity and Judicial Interpretation of Human Rights, 19 EuR. J. INT'L L. 655, 693 (2008), offers an analysis of dignity as the basis for human rights which concludes that dignity provides a convenient language for the adoption of substantive interpretations of human rights guarantees which appear to be highly contingent on local circumstances. In particular, dignity appears to be the justification for a stand-alone right to sanitation although (1) factual situations in which it could serve as basis for protection are already covered by other human rights, and (2) the multiplication of human rights is identified as a threat. See U.N. Human Rights Council, Promotion and Protection, supra note 82, at 19-20. 
Here is a final paradox: late-modern legal, social, and linguistic theory has taught us that rules, whether extracted from behavior or texts, are of necessity indeterminate. Thinking of human rights in terms of legal rules will extend indeterminacy into those rights as well. The secularization of human rights rhetoric involved in its becoming mainstream, then, may not be the best way to protect human rights. By remaining in the periphery, in the field of largely subconscious, private, moralreligious experience that defies technical articulation, human rights may be more able to retain their constraining hold on the way most people, and by extension most states, behave. ${ }^{106}$

Whatever their fundamental nature, human rights conceived as claims might sometimes be shorn of corresponding duties imposed on clearly defined duty-bearers in the development discourse. ${ }^{107}$ Moreover, traditional classifications, such as the three successive generations of negative, positive, and collective human rights-replaced progressively after 1980 by the tripartite typology of obligations to respect, protect, and fulfill for assessing the conduct of states regarding all human rightshave been dismissed as intellectual straightjackets with little analytical value. ${ }^{108}$ In the absence of a fixed anchor to establish a conceptual framework for the assessment of human rights, determining whether a human right has been violated or fulfilled can be difficult, especially with respect to socioeconomic rights since their realization is deemed progressive. ${ }^{109}$

106. Martti Koskenniemi, The Pull of the Mainstream, 88 Mich. L. Rev. 1946, 1962 (1989).

107. For example, UviN, supra note 33 , at 132 , notes that "many human rights are of an imperfect nature, meaning that it is not possible to match each rights claim with clearly corresponding duties and duty holders." Similarly, see U.N. Development Programme, supra note 64 , at 24-26. The difficulty to precisely match obligations and duties might stem from the tension between, on one side, the traditional form of international law in which the states, subjects of international law as opposed to individuals who are primarily its objects, agree to contractual obligations, and on the other side, human rights that deal with issues that are largely domestic and formerly considered part of the state's sovereign domain. See Frédéric Mégret, The "Special Character" of International Human Rights Obligations, in International Human Rights Law (Daniel Moeckli et al. eds., 2010).

108. See Ida Elisabeth Koch, Dichotomies, Trichotomies or Waves of Duties?, 5 Hum. RTs. L. Rev. 81, 82 (2005).

109. Recourse to the notion of core obligations does not seem to provide a firm basis. See Katharine Young, The Minimum Core of Economic and Social Rights: A Concept in Search of Content, 33 Yale J. INT'L L. 113, 163 (2008). The difficulty in determining violations to economic and social rights also raises questions about the effectiveness of international law, which is linked to the actual improvement in well-being of human rights-holders. Answers to these questions appear uncertain. See Oona Hathaway, Do Human Rights Treaties Make a Difference?, 111 Yale L. Rev. 1935, 1941 (2002). Contra Ryan Goodman \& Derek Jinks, Measuring the Effects of Human Rights Treaties, 14 Eur. J. INT'L L. 171, 172 (2003). 
As a result, human rights can hardly provide a stable and solid conceptual foundation for operational water resources management framework, either at the local or national level, which needs some degree of rigidity and permanency. ${ }^{110}$ For example, an attempt by governments to provide practical and concrete guidance to states for the realization of a human right justifying claims to water illustrates how human rights elusiveness can lead to the elaboration of nirvana concepts similar to expansive definitions of IWRM:

Bearing in mind that access to water in sufficient quantity and quality for all is fundamental for life and health, States should strive to improve access to, and promote sustainable use of, water resources and their allocation among users giving due regard to efficiency and the satisfaction of basic human needs in an equitable manner and that balances the requirement of preserving or restoring the functioning of ecosystems with domestic, industrial and agricultural needs, including safeguarding drinking-water quality. ${ }^{111}$

Second, many human rights justify claims to freshwater resources. The first set comprises rights that have a distinct, legal existence in the International Covenant on Civil and Political Rights (ICCPR) and the International Covenant on Economic, Social and Cultural Rights (ICESCR). ${ }^{112}$ An authoritative interpretation of some of these rights requires the availability of, and the physical accessibility to, the natural resources needed to feed oneself, which necessarily implies potentially

110. See Russells, supra note 43.

111. See U.N. Food and Agriculture Organization, supra note 96, Guideline 8C at 18, $\S 8.11$. This evasiveness is not limited to the right to food. For example, the core obligations detailed by General Comment 15, supra note 65, can be considered indeterminate. Hilary Grimes, Responding to the "Water Crisis": The Complimentary Roles of Water Governance and the Human Right to Water, 20 J. WATER L. 119, 124 (2009).

112. These seem to comprise at least the right to life pursuant to article 6 (1) ICCPR, the right to an adequate standard of living pursuant to article 11 ICESCR, the right to health according to article 12 ICESCR, the minority rights according to article 27 ICCPR, as well as the right to equal treatment pursuant to article 26 ICCPR. See BouRQUAIN, supra note 45 , at 198-99. The right to the highest attainable standard of health interprets the core obligations of states in relation to the right to the highest attainable standard of health as the obligation: "(b) To ensure access to the minimum essential food which is nutritionally adequate and safe, to ensure freedom from hunger to everyone; (c) To ensure access to basic shelter, housing and sanitation, and an adequate supply of safe and potable water." United Nations, Econ. \& Soc. Council, Comm. on Economic, Social and Cultural Rights, Substantive Issues Arising in the Implementation of the International Covenant on Economic, Social and Cultural Rights, General Comment No. 14, § 43, U.N. Doc. E/C.12/2000/4 (Aug. 11, 2000). 
vast quantities of water for agriculture. ${ }^{113}$ However, this list of rights is not exhaustive and can expand to include new human rights based on international customary law or on new contractual instruments. ${ }^{114}$ Two emerging rights in particular-the right to development and the right to a clean, healthy, or sustainable environment-could drastically broaden the scope of the HRBA with respect to water resource management. ${ }^{115}$

113. See United Nations, Econ. \& Soc. Council, Comm. on Economic, Social and Cultural Rights, Comment No. 12: The Right to Adequate Food, IIII 8, 12, 13, U.N. Doc. E/ C.12/1999/5 (May 12, 1999). It must be noted that since these paragraphs are part of the core content of the right to food, they should impose immediate obligations to states. Agriculture apparently claims 70 percent of total freshwater anthropogenic uses. From an individual perspective, producing food requires from 2,000 to 5,000 liters per day (lpd), depending on diet and climate differences and the efficiency of local food production systems. Food \& Agriculture Organization and International Fund for Agricultural Development, Water for Food, Agricultural and Rural Livelihoods, in UNESCO, Water a Shared Responsibility, U.N. World Water Dev. Rep. No. 2, 247 (2006). On the conflict between the right to food and a right to water, see Amanda Cahill, "The Human Right to Water-A Right of Unique Status": The Legal Status and Normative Content of the Right to Water, 9 INT'L J. OF Hum. RTs. 389, 401-402.

114. Variability with respect to the number of human rights is illustrated by JONES, supra note 53, at 85 . Illustrating the multiplicity of rights possibly referred to in relation to water resources, World Health ORG., supra note 35, at 21, notes the impact of the right to cultural life and the right to work. It must be noted that principle 2 of the U.N. Memorandum of Understanding cited in Part II.B seems to broaden the scope of the HRBA enough to include emerging human rights which are not strictly part of the general international human rights treaty law. The human right to sanitation is the perfect example of a new human right justifying a claim on water that has materialized over the last two years in international development discourse. See U.N. Human Rights Council, Promotion and Protection, supra note 82; COHRE ET AL., supra note 81; The Right TO SANITATION IN NATIONAL Laws (Henri Smets, ed., 2009). At the moment, the international discourse refers simultaneously to the existence of a stand-alone human right to sanitation (e.g., U.N. Human Rights Council, Promotion and Protection, supra note 82, often implied in the expression "human rights to water and sanitation") and a human right to water and sanitation (e.g., Resolution on the Human Right to Water and Sanitation, supra note 4). Such a phenomenon might contribute to the elusiveness of human rights as determinate conceptual anchors for prospective water resources management frameworks.

115. With respect to the right to development, see The Right to Development, G.A. Res. 54/175, U.N. Doc. A/RES/54/175 (Feb. 15, 2000); Economic, Social and Cultural Rights, 119 (Asbjrn Eide, Catarina Krause \& Allan Rosas, eds., 2d ed. 2001). Particularly important is the fact that the rights to food and clean water are fundamental human rights for the right to development according to $\S 12$ (a) of the General Assembly Resolution on the right to development discussed above. Would the realization of the right to development imply water resources consumption on a global scale in quantities similar to per capita consumption in developed countries such as Canada? Of specific concern with respect to the right to development in the present context is the conclusion of Upendra Baxi, The Development of the Right to Development, in Human Rights: New Dimensions and ChalLENGES 99, 114 (Janusz Symonides, ed., 1998), that recognition of the right to development should result in the proliferation of whole constellations of component rights. Significantly, concerns with logical consistency will block arguments against the relevance of the human 
This expansion continues if human rights, which are formally recognized in regional instruments or in rational law, and which might offer efficient recourses, are not dismissed as irrelevant to the HRBA to development. ${ }^{116}$

Third, human rights are often conceived as universal, indivisible, interrelated, and interdependent. ${ }^{117}$ There is no hierarchy between human rights, no right is more important than another. Rather, the realization of one set of rights paves the way for the realization of others. As a result, equal priority should be accorded to all human rights. ${ }^{118}$ How-

right to development when reference is made to the U.N.'s Resolution on the Human Right to Water and Sanitation, because the validation of the human right to development notably relies on the same type of instrument. With respect to the right to a clean environment, see Salman M.A. Salman, supra note 51; Melissa Fung, The Right to a Healthy Environment: Core Obligations Under the International Covenant of Economic, Social, and Cultural Rights, 14 WILLAMETTE J. INT'L L. \& Disp. Resol. 97, 105 (2006). This right could require the implementation of an extensive conservation regime for water resources to ensure sustainable ecosystems. It also implies that the HRBA to water encompasses water required for ecosystem needs. Dinara Ziganshina, Rethinking the Concept of the Human Right to Water, 6 SANTA Clara J. INT'L L. 113, 125-27 (2008); David Brooks, Human Rights to Water in North Africa and the Middle East: What Is New and What Is Not; What Is Important and What Is Not, in Water as a Human Right for the Middle East and North Africa, 24-27 (Asit Biswas, Egal Rached \& Cecilia Tortajda eds., 2008). Also illustrative in this context, a perceived conflict between the human rights to development and to a healthy environment has led to a suggestion that the time for a new human right to sustainable development has come in order to reconcile the formers, thereby potentially compounding the problem created by the multiplication of claims to water based on different human rights. See Sumudu Atapattu, The Right to a Healthy Life or the Right to Die Polluted?: The Emergence of a Human Right to a Healthy Environment Under International Law, 16 TuL. ENVTL. L.J. 65, 102 (2002).

116. As mentioned above, the right to property can be conceived as a human right expanding the HRBA to development in the water sector. See American States, supra note 56 . This observation is relevant although the covenants do not protect the right to property. This right is entrenched in regional treaties and is included in the Universal Declaration of Human Rights. Given the common referral to human rights in regional treaties for inferring an obligation to provide an adequate domestic or drinking water supply, it would seem inconsistent to exclude the right to property from the scope of the HRBA to water as currently defined since it has been demonstrated that the right to property protects access to sources of water for domestic purposes. On referral to regional sources of international law, see, e.g., UNESCO, International Experts' Meeting on the Right to Water, Paris, France, July 7-8, 2009, Outcome of the International Experts' Meeting on the Right to Water 1, 3 (July 7-8, 2009). However, at that point, it would appear difficult to limit the HRBA's scope to anything less than the entire domain of existing water management regimes. Layers of complexity can be further added by the fragmentation of the human right to property in a loosely overlapping human right to land that could also be linked to claims on water resources. On the human right to land, see Olivier De Schutter, The Emerging Human Right to Land, 12 InT'L Comm. L. Rev. 303 (2010).

117. See Vienna Declaration and Programme of Action, supra note 51, at sec. I, art. 5, 8 .

118. Belinda U. Calaguas, The Right to Water, Sanitation and Hygiene and the Human Rights-Based Approach to Development, 5 (WaterAid Briefing Paper, 1999), http://www. 
ever, as discussed previously, the HRBA to development in the water sector must deal with conflicts in allocating water resources to satisfy different human needs that generate tensions between various human rights, such as the right to drinking water versus the right to food. ${ }^{119}$ Access to water for domestic purposes can be justified through various legal instruments that might be related to different human rights. For example, a statutory right to water via a municipal supply and covered by the right to environment quality could conflict with a property right granting access to water for domestic purposes. ${ }^{120}$ If the HRBA recognizes both of these rights, the principle of indivisibility and the absence of any hierarchy would hamper conflict resolution. In this context, the

righttowater.info/wp-content/uploads/humanrights.pdf (stating that human rights are indivisible, they all have equal status as rights, and thus cannot be ranked, a priori, in a hierarchical order).

119. As mentioned at various points above and in particular Tarlock, supra note 92, allocation of water required for direct human consumption and for agriculture might conflict. With respect to the economic management of water services in Part III.D, it is noted above that there are tensions between a right to water and a right to nondiscrimination. The challenge in balancing these problems remains even once the discourse on the indivisibility and nonhierarchical nature of human rights is set aside by agreeing that domestic uses should be prioritized. See U.N. Human Rights Council Rep. of the United Nations High Comm'r for Human Rights on the Scope and Content of the Relevant Human Rights Obligations Related to Equitable Access to Safe Drinking Water and Sanitation Under International Human Rights Instruments, 25 § 62, Aug. 16, 2007, U.N. Doc. A/HRC/6/3 (2007) [hereinafter U.N. Human Rights Council Rep. on Scope and Content].

120. For example, in Lambton (Municipalité de) v. Stanscia, J.E., 2006 QCCS 5484 (Can. Que.), a municipality providing drinking water supply in conformity to the EQA, supra note 81 , is denied an order from the Court to seal a private well sunk and used for domestic purposes by one of the municipality's customers although the well might contaminate the municipal groundwater source. In this instance, an expansive interpretation of the HRBA would require that both accesses to water provided by the municipal supply and the private well be considered undividable and impossible to prioritize because both are granted through human rights. Indeed, property over land confers rights to use the private well whereas the statutory regime under which the municipality operates its water infrastructure is integral to the right to a healthy environment. See Civil Code of Québec, R.S.Q. 1991, c. 64 , arts. 947, 951, 979, 980 \& 981 (Can); Environmental Quality Act, R.S.Q. 2001, c. 35, art. 19.1-19.3 (Can.); Environmental Quality Act, R.S.Q. 1988, c. 49, art. 32 (Can.); Environmental Quality Act, R.S.Q. 1999, c. 40, art. 32.1 (Can.); Environmental Quality Act, R.S.Q. 1977, c. 55, art. 45 (Can.); Charter of Human Rights and Freedoms, R.S.Q. 1975, c. 6, art. 6 (Can.); Charter of Human Rights and Freedoms, R.S.Q. 1975, c. 6, art. 8 (Can.); CHRF, supra note 81, arts. 6, 8 \& 46.1; Jean Hétu \& Jean Piette, La Protection Juridique de L'ENVIRONNEMENT Au QuÉbec [LEgal protection FOR the ENVIRONMENT IN Quebec] 113 (1982) [Fr.]; Michel Gagné \& Mira Gauvin, Le droit à un environnement sain et respectueux de la biodiversité: valeur symbolique ou effet concret? [The Right to an Environment That Is Clean and Respectful of Biodiversity], in Développements Récents EN DROIT DE L'ENVIRONNEMENT 1 (Barreau du Québec ed., 2009) [Fr.]. If equal priority is granted to the right to a healthy environment and the right to property according to the HRBA, conflict between the well owner and the municipality can become intractable. 
blurred demarcations between rights and the difficulty in establishing a prioritization of water uses impede the development of a concrete management framework. The problem of nonhierarchical human rights claims to a limited resource is illustrated by the following:

In water stress and water scarce regions where competition for use of water is intense between domestic and agricultural sectors, a [Basic Water Requirement (BWR)] of 20-50 lpd is an empty concept. Using 1990 data, Gleick (1998) lists 55 countries where domestic per capita water withdrawals failed to provide $50 \mathrm{lpd}$. In eight of these countries, the aggregate of all sectoral uses of water failed to achieve the BWR. ${ }^{121}$

As a result of the ever-growing number and expanding scope of human rights relating to water resources, the HRBA to development might be compelled to offer a complete management framework applicable to all aspects of water resources. ${ }^{122}$ At that point, the conceptual distinction and added value of the HRBA would be weakened. Moreover, the over-extension of the HRBA might not always be desirable because resorting to human rights is essentially reactive rather than preventive: From a positivist standpoint, human rights are conceived as curative means to redress harms or imbalances. ${ }^{123}$ The historical evolution of human rights seems to demonstrate that enjoyment of the object of a human right must be denied to a number of individuals for a significant period before the right materializes. The development of a management regime for water resources based on human rights also requires long interpretative leaps within formal and constrained processes-essentially judicial—that are geared toward universal aspirations. These characteris-

121. Calaguas, supra note 118 , at 10-11. The citation goes on to say: "Nevertheless, those who advocate for the BWR state that the specific amount is less important than the principle of setting a goal (a basic water requirement that would be a standard), so that actions can be planned, implemented, and monitored." Id. The figures quoted come from Peter Gleick, The Human Right to Water, 5 WATER POL'Y 487, 496-98 (1999).

122. The scope of General Comment 15 , supra note 65 , illustrates this point abundantly, as do attempts to identify and detail the interface between human rights and duties. See Jonsson, supra note 39 , at 50 .

123. For example, in Zander v. Sweden (No. 14282/88), 279a Eur. Ct. H.R. (ser. A) 38 (1993), the groundwater nearby the plaintiff's well was already contaminated by cyanide at the onset of the case. In R. v. 974649 Ontario Inc., the Supreme Court of Canada states: "To the extent that it is difficult or impossible to obtain remedies for [Canadian Charter of Rights and Freedoms] breaches, the Charter ceases to be an effective instrument for maintaining the rights of Canadians. . . . [A] right, no matter how expansive in theory, is only as meaningful as the remedy provided for its breach." R. v. 974649 Ontario Inc., [2001] 3 S.C.R. 575 paras. 1,20 (Can.) (referring to $\S \S 1,17-24$ of the Charter). See also U.N. Human Rights Council, Promotion and Protection, supra note 82, at 17 (§ 52), 19-20. 
tics are difficult to harmonize with the adaptability and subsidiarity required from preventive and inclusive water resources management regimes at the local level.

In this context, the vagueness, multiplicity, expanding scope, indivisibility, and nonhierarchical nature of human rights would reduce the ability of the HRBA to act as a stable regime for prospective resource management. To minimize the challenges noted in this section, several questions should be addressed by water management frameworks. ${ }^{124}$ Should a human right to water-or indeed a human right to sanitationbe mentioned given that existing human rights cover similar expanses? ${ }^{125}$ Should human rights be portrayed as nonhierarchical and indivisible in relation to water resources management? Should a hierarchy of rights be established, as implied by the U.N. Human Rights Council? ${ }^{126}$ Should relevant human rights be quantitatively benchmarked to defined volumes of water? ${ }^{127}$ Should the HRBA to water be benchmarked to specific water quality? ${ }^{128}$ Is such benchmarking possible, acceptable, or feasi-

124. Merrills, supra note 52 , at $666,668-69,675$, offers a pragmatic view to avoid most of the pitfalls indicated in this subsection (Part III.E). The human rights doctrine offers examples of processes to address issues of rights prioritization and multiplication, notably in situations of resource scarcity. See BILCHITz, supra note 62, at 75-101.

125. The existence of a human right to water is the object of a debate in the literature. In favor, see Richard Hiskes, Missing the Green: Golf Course Ecology, Environmental Justice, and Local "Fulfillment" of the Human Right to Water, 32 Hum. RTs. Q. 326, 328-29 (2010); Langford, supra note 73. Against, see Stephen Tully, A Human Right to Access Water? A Critique of General Comment 15, 23 Neth. Q. Hum. RTs. 35, 37 (2005). For two authoritative views offering prudent conclusions on the existence of a human right to water in international law, see Stephen McCaffrey, The Human Right to Water, in Fresh WATER AND INTERnAtional EcoNOMIC LAW 115, supra note 84, at 115; Scanlon, Cassar \& Nemes, supra note 55, at 12 . Regardless of the positive legal existence of such a right (the evanescent nature of human rights discussed above might discourage attempts to conclude this debate), the essential point is that recognition of a human right to water at the international level is clear enough to compel the HRBA as defined in the U.N. Human Rights Based Approach to Development, supra note 40 , to consider the human right to water as one of the human rights forming its normative basis.

126. The U.N. Human Rights Council Rep. on Scope and Content, supra note 119, seems to prioritize water resources for the right to health.

127. Melvin Woodhouse, Threshold, Reporting, and Accountability for a Right to Water Under International Law, 8 U. Denv. WATER L. Rev. 171, 177-82 (2004-2005), argues that defining a minimum quantity requirement is not only a necessity for the implementation and the monitoring of the right but also for engineering practice, water sector professionals, and domestic policies. This question is detailed in GUY HowARD \& JAMIE BARTRAM, Domestic Water Quantity, Service, Level and Health 1, 3 (2003) and Peter Gleick, Basic Water Requirements for Human Activities: Meeting Basic Needs, 21 Water InT'L 83, 84 (1996). For more developments on this question, see infra Part IV.B.

128. This would be contrary to World Health OrG., Guidelines fOr Drinking-Water QUALITY, supra note 77, at 31-42, which indicates the necessity for contextualization, local risk assessment, and cost-benefit balancing for water quality standards. 
ble? ${ }^{129}$ Can a human rights-based management framework provide prospective solutions to possible but uncertain reduction in the life expectancy of groups of persons exposed to specific diffuse agricultural contaminants released in aquifers further to private activities undertaken in contravention to applicable regulations? What if regulation on diffuse agricultural pollution has not been enacted for lack of resources enabling effective aquifer monitoring? Is the HRBA equipped to deal with such questions on its own, or could it be complemented by scientific inputs? If so, are the statistical approaches that are often adopted to determine adequate public health policy objectives with respect to water management compatible with the protection of human rights from the perspective of a specific individual?

\section{INTERACTIONS BETWEEN IWRM AND THE HRBA TO WATER: THE SYNERGIES}

This Part details how IWRM and the HRBA to water complement each other. Synergies between IWRM and the HRBA result from each approach's capacity to compensate for the other's imperfections. On one side, integrated frameworks must be supported by discursive recourses to redress inescapable structural imperfections in water management regimes. Human rights-based recourses in the water sector should fulfill this role. On the other side, a comprehensive management regime for water resources cannot rely strictly on the HRBA to water because the core principles of this approach do not coexist easily with the technical methods required for adequate prospective water management.

To illustrate how conjoining the HRBA with integrated management frameworks may improve governance, the approach's impacts on water law at the national level are examined in three ways. ${ }^{130}$ First, the influence of the HRBA at the policymaking level is established (Part IV.A). Second, the importance of human rights-based claims as discursive tools to complement integrated water management frameworks is determined (Part IV.B). Finally, opportunities to foster the compatibility of the two approaches are suggested (Part IV.C).

129. U.N. Doc. A/HRC/11/13, U.N. General Assembly, supra note 99, at 16-17, suggests standards setting to progressively realize human rights to water.

130. The interactions between IWRM and the HRBA extend to all aspects of water governance. Covering all these aspects is not possible in the context of this article. National water law is an appropriate domain to study the interplay between the two approaches, because law is a fundamental element of IWRM and has a crucial relationship to human rights. See Sen, supra note 104, at 2914. According to Jonsson, supra note 39, at 60, "HRBAP focuses on legal and institutional reform, and promotes the rule of law." 


\section{A. Upstream: The Influence of the HRBA at the Policymaking Level}

National water law determines how natural hydrological patterns can be legally altered by human activities. ${ }^{131}$ Water law covers all activities related to water in jurisdictions in which the rule of law is considered a founding principle of social organization because the ultimate arbitration between competing societal interests over water resources takes place within the legal domain. ${ }^{132}$ Where violence is prohibited and the rule of law recognized, law offers a specific outcome to a situation in which a party is adversely affected by anthropogenic impacts on water resources. ${ }^{133}$ This viewpoint does not attempt to minimize the importance of non-legal customary norms, which can play a crucial role in preserving traditional communities, but simply reflects the ineluctable extension of law's domain under the current state model of social organization. ${ }^{134}$ Law's hegemonic proclivity in the normative domain can be illustrated as follows:

131. The definition of water law provided by Dante Caponera and Marcella Nanni helps to explain the scope of this statement. DANTE CAPONERA \& MARCELla NANNI, PRINCIples of Water LaW and Administration 49 (2d ed. 2007).

132. This assertion does not negate the prevailing reality of imperfect legal implementation and competing informal power structures. See, e.g., Armando Gevara-Gil, Water Rights and Conflicts in an Inter-Andean Watershed: The Achamayo River Valley, Junin, Peru, in Out of the Mainstream: Water Rights, Politics and Identity 183, 184 (Rutgerd Boelens, David Getches \& Armando Gevara-Gil eds., 2010). The assertion simply acknowledges the attempt of positive legal frameworks to encompass all possible social realities in self-referential systems. According to Pierre MoOr, Pour une théorie Micropolitique DU Droit 171 (2005), law must, and does, answer any question asked of it, albeit sometimes by default.

133. The dynamic extension of law's application domain to encompass nonlegal rules is evidenced even in situations where indigenous customary norms are upheld to protect traditional livelihoods. See, e.g., Mayagna (Sumo) Awas Tingni Community v. Nicaragua, Merits, Reparations, and Costs, Judgment, Inter-Am. Ct. H.R. (ser. C) No. 79, IIII 153, 173 (Aug. 31, 2001); Jonathan Vuotto, Awas Tingni v. Nicaragua: International Precedent for Indigenous Land Rights? 22 B.U. INT'L L.J. 219, 227-28 (2004). The recent case of the Kalahari Bushmen's right to access traditional water sources in a game reserve provides another example of positive law's monopoly in the normative domain with respect to the legal exercise of coercion. See Mosetlhanyane et al. v. Att'y Gen. (2011) Civ. App. No. CACLB-074-10 (Jan. 27, 2011) (Bots.), available at http://www.elaw.org/system/files/bs.mosetlhanyane.jan 2011.pdf.

134. For in-depth studies of the interface between customary norms and rights, see Tor Benjaminsen \& Christian Lund, Formalization and Informalization of Land and Water Rights in Africa: An Introduction, 14 Eur. J. Dev. Res. 1 (2002); Ruth Meinzen-Dick \& Leticia Nkonya, Understanding Legal Pluralism in Water Rights: Lessons From Africa and Asia, Address at the International Workshop on African Water Laws: Plural Legislative Frameworks for Rural Water Management in Africa (Jan. 26-28, 2005); Faustin Maganga, The Interplay Between Formal and Informal Systems of Managing Resource Conflicts: Some Evidence from South-Western Tanzania, 14 Eur. J. Dev. Res. 51 (2002). Ultimately, some commentators trace back the reduction of the social sphere inhabited by traditional and customary patterns of regulation 
A local dispute over de facto water rights is subject to pertaining social norms and practices-and risks being solved along with traditions and even a "might makes right" approach. However, if escalated to state authorities or to the courtroom, the dispute will be measured by standards of formal law because the state system claims exclusive validity and applies a certain procedural frame. Even a judge of the soft, inclusivepositivism school cannot recognize "rights" which are merely perceived as de facto rights in the local context. ${ }^{135}$

In this context, the HRBA can point to deficiencies in water law as a dispute-resolution mechanism between different water usages. For example, the percolation of a specific mining contaminant into an aquifer used for domestic purposes might lead to a lawsuit by a well owner against the polluter. ${ }^{136}$ Depending on the relevant national law, the action could be dismissed because the polluting activity conforms to applicable statutory provisions, and thus constitutes a normal annoyance that legally infringes on the property right of the well owner. In the absence of wells or permanent human presence in the vicinity of the mining discharge, national law might not even offer a possibility to sue the polluter due to lack of standing. In such a case, the existing legal framework effectively prioritizes the polluter's right to degrade water over the well owner's right to use water for domestic purposes and/or the right to a healthy environment.

This hypothetical example illustrates that when national law provides answers to societal conflicts over water resources, the solutions provided might not conform to the best standards of practice in water management. This is compounded by the fact that legal frameworks for water management are still fragmented in most countries around the

to the very concept of human rights. See Costas Douzinas, The End(s) of Human Rights, 26 Melb. U. L. Rev. 445, 459 (2002). The homogenization process of culturally discrete phenomena is apparent in some studies that aim at protecting both cultural patterns and access to water for the poor, the disenfranchised and the marginalized. See, e.g., Bill Derman \& Anne Hellum, Neither Tragedy Nor Enclosure: Are There Inherent Human Rights in Water Management in Zimbabwe's Communal Lands?, 14 Eur. J. Dev. Res. 31 (2002); Bill Derman, Anne Hellum \& Pinimidzai Sithole, Intersections of Human Rights and Customs: A Livelihood Perspective on Water Laws, Address at the International Workshop on African Water Laws: Plural Legislative Frameworks for Rural Water Management in Africa (Jan. 26-28, 2005).

135. Grönwall, supra note 53 , at 272-73.

136. Selection of the interface between mining and basic human water needs as an illustrative example reflects the observation that a disconnection exists between water management and human rights in mining. Deanna Kemp et al., Mining, Water and Human Rights: Making the Connection, 18 J. CLeaner Prod. 1553, 1556-57 (2010). 
world. ${ }^{137}$ Many laws and regulations manage water appropriations for irrigation, hydropower generation, industrial discharges, and water and sanitation services, with little consideration for their inter-sectoral impacts. In the mining example above, this can result in the licensing of polluting activities without taking into account effects on other water users. ${ }^{138}$ This fragmentation of water management frameworks perpetuates the continued degradation and over-exploitation of water resources at the international, regional, and local levels.

In response to these challenges, progressive reform and integration of national water laws should include aspects inspired by and based upon international human rights. ${ }^{139}$ Adopting the HRBA's core values can improve national water law where the existing legal framework allows water appropriation and pollution without consideration of the negative impacts on basic human well-being. For example, existing legislation might allow an executive agency responsible for the administration of a groundwater permit system to authorize large water extractions for mine dewatering even if it results in the drying-up of nearby domestic wells. In this context, the influence of the HRBA at the policymaking level might compel the legislating authority to amend its permit system in order to force the executive agency to consider domestic uses when granting groundwater permits. ${ }^{140}$

137. See Dante A. Caponera, The Inadequacy of Water Resources Legislation, in NATIONAL and International Water Law and Administration: Selected Writings 137, 138 (2003); Dante A. Caponera, Overview of Systems of Water Administration, in NATIONAL AND INTERNAtional Water LaW and Administration: Selected Writings 143, 144 (2003).

138. Legal frameworks for environmental protection and natural resources management often rely on a general interdiction to alter the environment complemented by a preliminary authorization regime, applicable to various activities altering the environment, which grants limited rights to pollute. In such cases, once an authorization is granted, the statutory remedies for violation of the general interdiction cease to be applicable against the authorized polluting activity. See, e.g., articles 19.2 \& 19.7 EQA, supra note 81 . This does not extinguish all remedies, as general private law recourses may nevertheless be used against the polluter (common law actions in tort and trespass or civil law recourses against neighboring annoyances or in extra-contractual liability). See Ciment du Saint Laurent Inc. v. Barrette [2008] 3 S.C.R. 392 (Can.), paras 32-36, 87-94 (in a case of atmospheric pollution under the EQA regime, applicable mutatis mutandis to water pollution). For thorough reflection on the interface between water pollution and permit systems, see A. DAN TARLOCK et Al., Water Resource Management: A Casebook in Law and Public Policy 655, 687-88 (6th ed. 2009).

139. To the extent that IWRM emerged before the Dublin Principles and that previous iterations of this approach did not mention a human right to water, the inclusion of such a mention under the fourth Dublin Principle can be conceived as evidence of the HRBA's influence at international policy level on IWRM itself.

140. "Integrating human rights effectively into state law, policy and practice, and establishing the promotion of justice as the aim of the rule of law, can play a critical role in redressing injustices related to the water sector." Emilie Filmer-Wilson, The Human Right to 
In addition, the principles of prevention and precaution should remain critical aspects of national water law, due to long time-lags, incremental and diffuse impacts, and uncoupling between human actions and damages sustained by environmental resources and water users. ${ }^{141}$ For example, the pollution of a domestic well by mining activities might occur decades after discharge and might remain undetected. Even if pollution is detected, decontamination of the aquifer will generally be too costly or technically impossible in individual, human time-scales.

\section{B. Downstream: Human Rights-Based Recourses in National Water Law}

Legal recourses based on human rights at the national level are essentially curative means to redress harms or imbalances. For example, a national law might provide recourse based on a right to a healthy environment to the owner of a domestic well polluted by toxic mining contaminants. A lawsuit brought by the well owner might stop further pollution or result in the award of an adequate monetary compensation to find a new water source. However, courts might refuse to order the clean-up of an aquifer because the operation is technically or financially impossible and more costly than monetary compensation. In other words, even if the well owner's lawsuit is successful, domestic access to water may not be restored. ${ }^{142}$ Even if a statute providing a right to a

Water and the Human Right-Based Approach to Development, in The Human Right to Water 60 (Eibe Riedel \& Peter Rothen, eds., 2006). For a more general overview on the influence of international human rights at the national lawmaking level, see Hurst Hannum, The Status of the Universal Declaration of Human Rights in National and International Law, 25 GA. J. INT'L \& Comp. L. 287, 312-17 (1995-96); Christof Heyns \& Frans Viljoen, The Impact of the United Nations Human Rights Treaties on the Domestic Level, 23 Hum. RTs. Q. 483 (2001). On the other hand, the inconsiderate imposition of a top-down reform process based on exogenous legal principles and frameworks can alienate poor local communities from water management structures, even if such process is guided by human rights-based principles. See, e.g., Bill Derman et al., Intersection of Law, Human Rights and Water Management in Zimbabwe: Implications for Rural Livelihoods, in COMMUNITY-BASEd WATER LAW AND WATER ResourCe MANagement Reform in Developing Countries 248, 258-59 (Barbara van Koppen, Mark Giordano \& John Butterworth eds., 2007).

141. "Ideally, an aquifer would be managed so that it would not be polluted." Karin Kemper, Rethinking Groundwater Management, in Rethinking WATER MANAGEMENT: INNOvative Approaches to Contemporary Issues 120, 122 (Caroline M. Figuères, Cecilia Tortajada \& Johan Rockström, eds., 2003).

142. Comparative reviews of national water laws detail the usual sanctions for violations of provisions related to the management of water quantity and quality. See SALMAN M.A. Salman \& Daniel D. Bradlow, Regulatory Frameworks for Water Resources Management: A Comparative Study 138, 161 (2006); Stephano Burchi \& Ariella D'Andrea, Preparing National Regulations for Water Resources Management: Principles and Practice, FAO Legislative Study 80, 80-89, 167-71 (2003), ftp://ftp.fao.org/docrep/fao/006/y5051e/ 
healthy environment allows preventive action, delays in judicial processes, effects of scientific uncertainty on meeting the burden of proof, and financial imbalances between the parties reduce the likelihood of success in protecting the existing domestic access to water. In this context, the HRBA's downstream value in a legal regime might initially appear limited, especially when the rule of law is weak and access to justice restrained.

Nevertheless, human rights-based recourses to obtain water in adequate quantity and quality are essential. Integrative legal frameworks geared toward unified management solutions for environmental resources often fail to solve the issues they are designed to address. ${ }^{143}$ Water pollution and water shortages increase in both developing and developed countries that strive for IWRM implementation. A universal cause for this is that scientific, rational, and instrumental approaches are unable to provide solid prospective bases for optimizing the benefits of water management because of a lack of technical capacity and financial resources. Decision-making in the water sector invariably relies on the simplification of complex situations. ${ }^{144}$ This phenomenon is often presented as the inherent uncertainty of hydrological regimes, creating structural defects in resources management frameworks. As noted:

y5051e00.pdf. There is a recent tendency to protect water quality from pollution through precautionary and preventive measures. See id. at 144-67. Among such measures, provisions might be made for granting permits to mining companies conditional on financial guarantees to cover the costs of possible decontamination. Nevertheless, such measures remain marginal in scope, are relatively independent from right-based individual recourses, and cannot fully restore anterior water uses, especially since natural attenuation for groundwater remediation is a predominant solution. See National Research Council, Natural Attenuation for Groundwater Remediation (2000).

143. For some thoughts on these issues, see A. Dan Tarlock, The Future of Environmental "Rule of Law" Litigation, 19 PACE Envtl. L. Rev. 575, 592-97 (2002).

144. This inevitably results from processes of generalization and abstraction inherent in law-making, which are also generally present in all domains of activity relying on models and narratives. With respect to law on this issue, see LON L. FULLER, LeGal Fictions 93-137 (1967). According to BiLCHITZ, supra note 62, at 127,

[g]eneral decision-making across a range of cases can obscure the problems that may arise in particular instances to which that general decision may apply. . . . Legislative decisions, in particular, have the virtue of being general and applying to a range of cases. They may, however, overlook the dire effect that such policies may have in particular situations. Judicial decision-making concerning fundamental rights, on the other hand, usually arises as a result of a particular instance in which it is argued by an individual that the general law has dire consequences for the individual or group concerned.

(internal citation omitted). 
[A]n ecosystem is a complex, nonlinear, dynamic system. It is more than that it is complicated. Even if we had a relatively sophisticated scientific understanding of each of the components, there is likely to remain a residuum of inherent uncertainty and unpredictability with respect to the consequences of any particular input-including any adjustments we might make through management measures-due to the "inherent stochasticity" and continuously evolving nature of complex natural systems. . . . [This] has large implications for environmental law and natural resources management. Precisely because the last thirty years or so of sustained regulatory effort to protect the environment and critical ecological resources have not been based on this insight, we have constructed an architecture of laws and management systems that are poorly matched to the challenge of managing ecosystems as complex dynamic systems. ${ }^{145}$

Hence, any legal system governing groundwater extraction that is designed to preempt conflicts over water usage while maximizing social and economic benefits will be unable to prevent all future harms to individuals-and the ensuing claims. As a result, exclusive reliance on the rationalization and integration of prospective frameworks for water management is insufficient. ${ }^{146}$ Were human rights to provide justification

145. Bradley Karkkainen, Collaborative Ecosystem Governance: Scale, Complexity, and Dynamism, 21 VA. ENVTL. L.J. 189, 196-97 (2002-2003) (citations omitted).

146. The fundamental explanation for this failure could stem from ineluctable constraints applicable to the dialectic between order and disorder. If social and economic phenomena are ordered structures, then it is possible to speculate that these orderly structures are bound to unravel. See William Rees, Confounding Integrity: Humanity as Dissipative Structure, in Reconciling Human Existence with Ecological InTEgrity: SCIENCE, Ethics, EcoNOMICS AND LAW 293 (Laura Westra, Klaus Bosselmann \& Richard Westra, eds., 2008); M.H. Huesemann, The Limits of Technological Solutions to Sustainable Development, 5 CLEAN TECHNOLOGIES \& ENVTL. POL'Y 21 (2003). A less ambitious explanation for this failure concedes that social and economic phenomena are irreducibly complex and their structure escapes determination, but recognizes the deterministic tendencies of theories for social and economic organization and behavior. See Peter Stewart, Complexity Theories, Social Theory, and the Question of Social Complexity, 31 PHIL. Soc. SCI. 323 (2001). According to Göktug Morçöl,

Newtonian science is based on the belief that the universe is completely deterministic. The Newtonian deterministic view includes two sets of interrelated assumptions: that the relationships between entities and events are causal and that future events are predictable. It is assumed that entities and events relate to each other in a perfectly orderly and causal manner and that these relations are predominantly linear. . . . Consequently, future events are deemed to be precisely predictable. . . . In the Newtonian description of causality, external events cause changes in the positions and movements of objects. Newtonian science deals mostly with linear forms of causality (i.e., proportionate cause and effect relationships). Although 
and normative guidelines as well as detailed operational standards and benchmarks for all water management issues, thereby supporting an exhaustive system that prospectively cover future situations, such a management framework would become similarly afflicted with structural defects and discrete failures. ${ }^{147}$

Newtonian science recognizes some nonlinearities in its mathematical models, it still favors linear models. . . . The Newtonian notion of causality also includes the assumption that there are necessary connections between events (i.e., that the relations between past and future events are fixed, and no alternative futures are allowed). . . . The deterministic beliefs of Newtonian science have penetrated the theoretical thinking in public policy and administration. Newtonian beliefs manifest themselves particularly in the theories of long-term planning and bureaucratic organization. In long-term planning, the assumption is not only that government actions and programs can cause desired effects (effects such as economic growth and manufacturing of goods at desired levels) but also that the relationship between cause and effect is linear, proportional. To obtain a desired amount of economic growth, a proportionate amount of monetary or non-monetary incentives are injected into the economic system.

Göktug Morçöl, A New Systems Thinking: Implications of the Sciences of Complexity for Public Policy and Administration, 29 Pub. Admin. Q., 297, 299-301 (2005). In this case, it is simply the management paradigms themselves as blueprints for programming social organization that fail to meet reality's incondensible complexity. From this point of view, attempts such as that of Claudia Pahl-Wostl might ultimately come undone. C. Pahl-Wostl, The Implications of Complexity for Integrated Resources Management, 22 EnvtL. Modelling \& Software 561 (2007). And so would any legal framework conceived as a normative system reflecting social networks and interactions, and designed with the intent to integrate all aspects of resources management. Whichever of the two explanations is preferred, the assertion above appears valid.

147. There are no principles of justice that can deliver a set of rights that do not contain contradictory judgments-i.e., structural defects-about the permissibility of actions. Keith Dowdings \& Martin Van Hees, The Construction of Rights, 97 Am. Pol. Sci. Rev. 281 (2003). The drive to turn approaches to development based on human rights into all-encompassing prospective management frameworks is most apparent in the literature on human rights indicators and emerging concepts such as human rights impact assessment. See Paul Hunt \& Gillian MacNaughton, Impact Assessments, Poverty and Human Rights: A Case Study Using the Right to the Highest Attainable Standard of Health (World Health Org., Working Paper No. 6, 2006), available at http://www.who.int/hhr/Series_6_Impact\%20Assessments_Hunt_ MacNaughton1.pdf; Todd Landman et Al., U.N. Dev. Programme, Indicators for Human Rights Based Approaches to Development in UNDP Programming: A User's Guide (2006); U.N. Secretary-General, Human Rights Impact Assessments: Resolving Key Methodoligical Questions, U.N. Doc. A/HRC/4/74 (Feb. 5, 2007) (discussing human rights and transactional corporations and other business enterprises). Interestingly, Sakiko Fukuda-Parr, Terra Lawson-Remer, and Susan Randolph propose to measure the fulfillment of a series of social and economic rights, among which the human right to housing is singled out, to be tied to national statistics on access to improved water source and sanitation and to be expressed in one methodological version through the formula $\mathrm{z}_{4}=\left(.5 \mathrm{x}_{\mathrm{L} 7}+\right.$ $.5 \mathrm{x}_{\mathrm{L} 8}$ )/y. Sakiko Fukuda-Parr, Terra Lawson-Remer, \& Susan Randolph, Measuring the Progressive Realization of Human Rights Obligations: An Index of Economic and Social Rights Fulfill- 
Because of their inherent defects, rationalized and integrated legal frameworks for prospective management must be complemented by discursive instruments in order to redress structural imbalances and the resulting prejudices affecting basic human well-being, once they appear. ${ }^{148}$ Human rights can best perform this function because they are conceptually irrepressible claims, thus acting as the ultimate safeguard against systemic failure. These recourses are crucial in situations where legal frameworks remain unreformed and regime breakdown is more frequent. ${ }^{149}$ In this context, the incorporation of the core normative elements of the HRBA in national water law's structure is essential. The HRBA to development in the water sector is the driver for the materialization of human rights-based recourses at the national level. Examples of the functions performed by human rights-based claims brought forward by individuals in a national legal framework are as follows:

- Obtaining the cancellation of an administrative authorization to use water for mining purposes because it is harmful to domestic uses;

- Overturning as unconstitutional a water allocation statute with excessive negative impacts on a river basin;

- Requiring a legislature to adopt a regulatory program for water protection or an administrative body to issue a water license. ${ }^{150}$

At this point it appears that, although they are necessary, integrated management structures cannot fully attain their objectives because they remain subject to discrete systemic failures. As a result, these structures must be complemented with discursive instruments in order to redress their failures, and human rights should be used for this because they constitute the most potent discursive instruments available.

One final consideration further stresses the need for emphasizing human rights' role as ex post recourses: To some extent, the HRBA use of human rights as structural tools for prospective management might weaken their potency as discursive instruments for redress. For example,

ment 15 (Univ. of Conn. Dep't of Econ., Working Paper No. 200822, 2008). The point is that such statistical indicators offer general frameworks for resources allocation which are compatible with the failure of human rights on an individual basis.

148. The need for individual recourses stems from the failures and weaknesses of resources and environmental management regimes. Bruce Pardy, Environmental Rights: Mitigating Flaws of the Management Model, 1996 N.Z. L. Rev. 239, 241-43.

149. See U.N. Dev. Programme, Human Development Report 2006: Beyond Scarcity: Power, Poverty and the Global Water Crisis 101 (2006).

150. For a generic list of different methods that courts might apply to enforce a constitutional right to a healthy environment that can serve as an illustration mutatis mutandis for human rights claims to water, see Svitlana Kravchenko \& John E. Bonine, Human Rights and the Environment: Cases, LaW, and Policy 72 (2008). 
the HRBA links the materialization of the human right to water in management frameworks to the guidelines for drinking-water quality developed by the World Health Organization. ${ }^{151}$ These guidelines are based explicitly on a cost-benefit approach that focuses first on critical threats to public health that cause the most harm to the largest number of people before moving to lesser health threats when and if resources allow. ${ }^{152}$ This approach is legitimate in a context of limited resources and progressive development. However, this cost-benefit approach to human rightsbased management implies exceptions in which basic human needs will not be covered. A minority of individuals will continue to suffer from non-prioritized water contamination. ${ }^{153}$ Through the attempt of the HRBA to provide standards-based prospective management, human rights become associated with regulatory regimes that maximize benefits for a majority by allocating costs to a minority. This requires assessing the extent to which a recourse based on a human right to water can be effective against a harm that is also justified by a human right to water.

This reference to quantitative and qualitative standards imbues human right claims to water with a determinate, non-relative content. It implies an underlying standardization of basic human water needs for groups of individuals regardless of discrepancies in concrete personal situations and needs. The ex ante standard setting required by the materialization of a determinate minimum core for human rights to water leads to the theoretical acceptance of exceptional situations where more or better water than actually required to cover basic human needs must be provided to a specific individual, but also to situations where less or worse water than actually required to fulfill basic human needs will be provided to a specific individual. ${ }^{154}$ Because of the latter possibility, the

151. See, e.g., General Comment 15, supra note 65 at $5 \S 12(\mathrm{~b})$; United Nations, Econ. \& Soc. Council, Comm. on Human Rights, Realization of the Right to Drinking Water and Sanitation, Report submitted by Special Rapporteur El Hadji Guissé, U.N. Doc. E/CN.4/ Sub.2/2005/25 (July 11, 2005) (stating that "[w]ater-quality standards should give priority to the elimination of the pollutants with the most significant impact on health in the particular country or context.").

152. World Health Org., supra note 77, at 2.

153. Parmar, supra note 66 , at 86 , illustrates how the conjunction of development with the human rights language in the context of water resources management can justify the suffering of some. The coexistence of the drive to attain developmental objectives with the human rights-based refusal to contextualize individual violations generates internal tensions within the HRBA. See Robert Archer, Linking Rights and Development: Some Critical Challenges, in Rights-Based Approaches to Development: Exploring the Potential and Pitfalls 21, 24 (Sam Hickey \& Diana Mitlin eds., 2009).

154. Ex ante means "Based on assumption and prediction on how things appear beforehand, rather than in hindsight." Black's LAW Dictionary 642 (9th ed. 2009). 
idea of ex ante determination of a standardized minimum core for human rights to water must be considered with caution. ${ }^{155}$

\section{Streamlining: Reducing Interferences Between IWRM and the HRBA}

The synergies between integrated frameworks for prospective management and the HRBA to water do not eliminate the tensions resulting from their coexistence. As discussed previously, such tensions must be resolved contextually by water managers responsible for the elaboration and implementation of adequate water resources management frameworks at the local and national levels. ${ }^{156}$ Nevertheless, these tensions could be minimized through a series of practical steps.

First, some proponents of the HRBA to water describe this approach as rights-based rather than human rights-based. ${ }^{157}$ This blurs the distinction between water rights that constitute the basic building blocks of any water allocation framework, whether unjust or equitable, and human rights that have an impact on access to water for basic needs. ${ }^{158}$ Such a semantic slip renders the substantive content of the HRBA to

155. Protecting the conceptual integrity of human rights in case they conflict against each other can justify deviations from human rights standards and a relative conception of human rights universality. See Jack Donnelly, The Relative Universality of Human Rights, 29 Hum. RTs. Q. 281, 300-302 (2007). From this perspective, it can be argued that the ineluctable conflicts generated by the competition between human rights to water are best addressed by emphasizing the role of human right norms as ex post recourses that remain ex ante undefined, that is essentially relativistic.

156. This is to avoid the alienation process that results from the imposition of a topdown model on local stakeholders. See Rutgerd Boelens, David Getches \& Armando Guevara-Gil, Water Struggles and the Politics of Identity, in Out of THE MAINSTREAM: WATER Rights, Politics AND IDENTity 3 (Rutgerd Boelens, David Getches \& Armando Gevara-Gil eds., 2010).

157. See, e.g., World Health Org., supra note 35, at 9-10. An Overseas Developmental Institute (ODI) Briefing Paper from 2004 offers an example of an unsatisfactory typology of the various forms of a "right to water" that ultimately confuses the discourse on the HRBA. The three types of rights identified overlap and cannot actually be distinguished from each other through the determining characteristic assigned to them. Peter Newborne et al., ODI, Right to Water: Legal Forms and Political Channels (July 2004).

158. For a definition of water rights, see Stephen Hodgson, FoOd \& Agric. Org., Legislative Study Number 92: Modern Water Rights: Theory and Practice 4-9 (2006). For a legal context that differentiates human rights to water from rights to water, see Jan Hendriks, Water Laws, Collective Rights and System Diversity in the Andean Countries, in Out OF the Mainstream: Water Rights, Politics and Identity 165, 166-69 (Rutgerd Boelens, David Getches \& Armando Guevara-Gil eds., 2010); Arjun Kumar Khadka, The Emergence of Water as a "Human Right" on the World Stage: Challenges and Opportunities, 26 INT'L J. WATER Resources Dev. 37, 40-41 (2010). Hodgson, supra this note, at 95-96, states that the equity value of water rights-based approaches is uncertain. 
water significantly less certain because support for a rights-based approach might be cynically construed as support for the rule of law in national jurisdictions where the existing legal framework for water rights implicitly marginalizes women and the poor. The danger in confusing the two can be illustrated by the following:

Justification for some form of a rights-based approach might be founded on the rule of law. This however depends upon the meaning given to this constitutional concept. In one sense the rule of law is primarily a formal concept. It demands that there should be lawful authority for the exercise of power, and that individuals should be able to plan their lives on the basis of clear, open and general laws. On this hypothesis, the rule of law is not the rule of the good law, and its dictates can be met even by non-democratic societies. On this view, the rule of law cannot provide the foundation for particular substantive rights as such. ${ }^{159}$

A suggestion to avoid this problem would be to maintain consistency by always refering to the HRBA as a human rights-based approach. Semantic consistency would also pinpoint the substantive added value of human rights with respect to water resources management frameworks and water rights.

Second, the HRBA tends to expand to all aspects of water management because of the multiplication of human rights that can serve as a basis for claims on water resources. As seen above, this might generate significant tensions in reform processes aimed at improving water management frameworks because human rights as moral absolutes can offset the delicate balancing and fine-tuning of resource allocation and protection regimes. Professor John Merrills notes:

Rights and preferences tend to be confused-sometimes it must be said deliberately-because when there are conflicting demands, whether in relation to jam tarts or the environment, having the desired objective recognized as a right is a crucial means of establishing priorities. When preference confronts preference the result in moral terms is a stand-off. When right confronts preference, on the other hand, the holder of the right has a trump card with which to pre-empt preferences and other non-moral considerations. What is true here of moral rights is true a fortiori when such rights are translated into

159. Paul Craig, Administrative Law 22 (6th ed., 2008). For a conceptual discussion on the difference between the rule of law and human rights, see Evan Fox-Decent, Is the Rule of Law Really Indifferent to Human Rights?, 27 LaW \& PHIL. 533 (2008). 
law. . . . If rights are a good way of ensuring that something is taken seriously, designating an entitlement a human right is even better, on account of the status of this class of rights in legal and moral discourse. . . . [I]f a preference can be turned into a right, the position of the new rights-holder is much strengthened, especially in comparison with rivals whose preferences have not been so transformed. There may also be other effects, however. Suppose that instead of being confronted with a mere preference, our rights-holder is confronted with another rights-holder. We are now back to the same position of preference being confronted with preference, with the important difference that, as Lomasky has explained, since both parties are armed with rights, accommodation through compromise may now be much less appealing. The tendency for disputes to become more acrimonious when rights are at stake can also be seen elsewhere. A rights-holder confronted by a rival with a mere preference will expect to get his way, and, although the purpose of rights is to ordain such priorities, the natural tendency to "stand on our rights" cannot be said to do much to promote social harmony or, in some cases, social welfare. When there are only competing preferences, we can try to maximize social welfare by utilizing a cost-benefit analysis. However, once a preference is converted into a right, tradeoffs can no longer be considered in the same way. Moreover, a proliferation of rights and rights holders not only multiplies the opportunities for rights-holders to come into conflict with each other, but also generates a tension between rights as a basis for actions and other moral considerations. ${ }^{160}$

The HRBA scope should remain confined to areas of water management where its influence is essential and its impact significant. To avoid an unmanageable expansion of the HRBA, clearly identifying to which human rights the approach refers is crucial. For example, the HRBA could be defined to refer exclusively to the human rights formally recognized in international law through the ICESCR and the ICCPR. In particular, the challenge generated by some human rights that play a more significant role in extending the HRBA to entire management structures-such as the right to property, the right to development, and the right to a healthy environment-would be reduced, as these rights do not figure in the ICESCR and the ICCPR. All the necessary underlying requirements for the realization of the human rights contained in the covenants with respect to water resources will progressively materialize through the normal process of legal interpretation. This suggestion ulti-

160. Merrills, supra note 52, at 666-68 (internal citations omitted). 
mately corresponds to a trend in the literature that recommends a renewed focus on the positive legal manifestations of international human rights. ${ }^{161}$ It also underlines the importance of transposing these rights into national legal frameworks further to reforms motivated by human rights advocacy in order to offer ex post discursive recourses-recourses that provide remedies to ex ante indeterminate situations-against systemic failures in water resources management frameworks.

Finally, the rhetoric of human rights as equal, indivisible, interdependent, and interrelated hampers the necessary trade-offs between and the prioritization of various claims to limited water resources. ${ }^{162}$ For example, agricultural irrigation competes with intakes for urban waterworks. ${ }^{163}$ A confrontation between two equal human rights with absolute moral priority cannot provide elaborate apportionment mechanisms for limited water resources. ${ }^{164}$ As a result, limiting or even omitting the rhetoric of indivisibility and equal priority with respect to the HRBA to water may be necessary. ${ }^{165}$ In this respect, focusing on human rights recourses in national legal frameworks could provide an interesting avenue, since law as a means of conflict resolution through adversarial adjudication before the courts is ultimately impervious to the intractability that stems from the doctrine of indivisibility and interdependence: When a judge rules on the merits of a case, competing claims are inevitably either upheld or rejected, partially or in totality.

\section{CONCLUSION}

The HRBA to development in the water sector and IWRM, understood as a principle of integration that increases the coherence of prospective management frameworks for water resources, complement each other. Synergies between IWRM and the HRBA result from each ap-

161. See Siobhan McInerney-Lankford, Human Rights and Development: A Comment on Challenges and Opportunities from a Legal Perspective, 1 J. Hum. RTs. Prac. 51, 52 (2009); Russells, supra note 43; Fons Coomans, Fred Grünfeld \& Menno Kamminga, Methods of Human Rights Research: A Primer, 32 Hum. RTs. Q. 179 (2010).

162. See Lauchlan T. Munro, The "Human Rights-Based Approach to Programming": A Contradiction in Terms?, in Rights-Based Approaches to Development: Exploring the Potential and Pitfalls 187, 190-191 (Sam Hickey \& Diana Mitlin eds., 2009).

163. See Simon Cook et al., Water, Food and Livelihoods in River Basins, 34 WATER INT'L 13, 21 (2009).

164. See Merrills, supra note 52, at $666,668-69,675$.

165. This is different from a suggestion to repudiate that doctrine. The need to establish an order of priority among human rights is recognized in the HRBA discourse. See U.N. Dev. Programme, supra note 64, at 23. Amitai Etzioni, Life: The Most Basic Right, 9 J. Human RTs. 100, 100 (2010), emphasizes that scarcity justifies ranking human rights. On this subject, see also the debate surrounding James Nickel, Rethinking Indivisibility: Towards a Theory of Supporting Relations Between Human Rights, 30 Hum. RTs. Q. 984 (2008). 
proach's ability to enhance the other's impact on water resources management. On one hand, the integration of management systems is essential. On the other hand, the HRBA to water is required in order to bolster equity at the policymaking level and redress structural imbalances through discursive recourses.

These synergies do not eliminate the tensions identified by an integrated perspective on the HRBA to water. Answers must be provided to questions raised by discrepancies between: (1) the HRBA as a standardized anthropocentric approach and the need for an ecosystemic contextualization of claims on water resources; (2) the HRBA as an vehicle for developmental aspirations and the finite nature of water resources; (3) the blurred duties of right-holders in regards to the user-pays principle; (4) economic water management and the need to protect marginal groups and the poor; and (5) the evasiveness of the HRBA and the need for a stable and consistent framework for prospective water management.

The tensions between IWRM and the HRBA must be resolved contextually by local water managers and stakeholders at the ground level. Generic answers to such issues would perpetuate the problems created by the inconsiderate transplant and imposition of alien models and narratives on social and environmental contexts to which they are not adapted. In particular, local and national initiatives need to address two theoretical challenges confronting the HRBA to development in the water sector: (1) the unmanageable extension of the HRBA to all aspects of prospective water governance frameworks, and (2) the intractability of conflicts between human rights with respect to water. 